\begin{tabular}{|c|c|c|c|l|l|}
\hline \multirow{2}{*}{ 2 } & S E D & 12340 & \multirow{2}{*}{ WILEY } & Dispatch: 11.11.16 & CE: Gomathi \\
\cline { 2 - 3 } \cline { 5 - 5 } & Journal Code & Manuscript No. of pages: 38 & PE: Sudhakar G. \\
\hline
\end{tabular}

\title{
From outwash to coastal systems in the Portneuf-Forestville deltaic complex (Québec North Shore): anatomy of a forced regressive deglacial sequence
}

\author{
PIERRE DIETRICH* , JEAN-FRANÇOIS GHIENNE*, MATHIEU SCHUSTER*, \\ PATRICK LAJEUNESSE $\dagger$, ALEXIS NUTZ*, RÉMY DESCHAMPS $\ddagger$, CLAUDE ROQUIN* \\ 2 and PHILIPPE DURINGER* \\ *Institut de Physique du Globe de Strasbourg, UMR 7516 CNRS/Université de Strasbourg, 1 rue \\ Blessig, 67084, Strasbourg, France (E-mail: pdietrich@unistra.fr) \\ $\dagger$ Centre d'Étude Nordiques and Département de Géographie, Université Laval, Pavillon Abitibi-Price, \\ 2405 Rue de la Terrasse, Québec, QC, G1V 0A6, Canada \\ $\ddagger$ Institut Français du Pétrole - Énergies Nouvelles, 1 \& 4 Av. de Bois-Préau, 92852, Rueil-Malmaison \\ 3 Cedex, France \\ Associate Editor - Christopher Fielding
}

\begin{abstract}
Deglacial sequences typically include backstepping grounding zone wedges and prevailing glaciomarine depositional facies. However, in coastal domains, deglacial sequences are dominated by depositional systems ranging from turbiditic to fluvial facies. Such deglacial sequences are strongly impacted by glacio-isostatic rebound, the rate and amplitude of which commonly outpaces those of post-glacial eustatic sea-level rise. This results in a sustained relative sea-level fall covering the entire depositional time interval. This paper examines a Late Quaternary, forced regressive, deglacial sequence located on the North Shore of the St. Lawrence Estuary (Portneuf Peninsula, Québec, Canada) and aims to decipher the main controls that governed its stratigraphic architecture. The forced regressive deglacial sequence forms a thick $(>100 \mathrm{~m})$ and extensive $\left(>100 \mathrm{~km}^{2}\right)$ multiphased deltaic complex emplaced after the retreat of the Laurentide Ice Sheet margin from the study area ca 12500 years ago. The sedimentary succession is composed of ice-contact, glacimarine, turbiditic, deltaic, fluvial and coastal depositional units. A four-stage development is recognized: (i) an early icecontact stage (esker, glacimarine mud and outwash fan); (ii) an in-valley progradational stage (fjord head or moraine-dammed lacustrine deltas) fed by glacigenics; (iii) an open-coast deltaic progradation, when proglacial depositional systems expanded beyond the valley outlets and merged together; and (iv) a final stage of river entrenchment and shallow marine reworking that affected the previously emplaced deltaic complex. Most of the sedimentary volume (10 to $15 \mathrm{~km} 3$ ) was emplaced during the three-first stages over a $c a 2 \mathrm{kyr}$ interval. In spite of sustained high rates of relative sea-level fall ( 50 to $30 \mathrm{~mm} \cdot \mathrm{year}^{-1}$ ), delta plain accretion occurred up to the end of the proglacial open-coast progradational stage. River entrenchment only occurred later, after a significant decrease in the relative sea-level fall rates $\left(<30 \mathrm{~mm} \cdot \mathrm{year}^{-1}\right)$, and was concurrent with the formation and preservation of extensive coastal deposits (raised beaches, spit platform and barrier sands). The turnaround from delta plain accretion to river entrenchment and coastal erosion is interpreted as a consequence of the retreat of the ice margin from the river drainage basins that led to the
\end{abstract}


drastic drop of sediment supply and the abrupt decrease in progradation rates. The main internal stratigraphic discontinuity within the forced regressive deglacial sequence does not reflect changes in relative sea-level variations.

Keywords Deglaciation, forced regressive delta, Holocene, St. Lawrence Estuary, Wisconsinan.

\section{INTRODUCTION}

Deciphering the cyclical patterns of ice sheet advance and retreat from the sedimentary record is crucial for understanding the behaviour of past ice sheets. The processes of deglaciation are commonly inferred from sedimentary successions that include ice-contact deposits (e.g. backstepping morainal banks) overlain by more ice-distal glaciomarine depositional suites (Boulton, 1990; Visser, 1997; Syvitski \& Lee, 1997; Lønne et al., 2001; Jakobsson et al., 2011; Carling, 2013; Batchelor \& Dowdes5 well, 2015). Yet, a wider spectrum of depositional systems, mainly including turbiditic, deltaic, lacustrine, coastal, tidal or fluvial deposits, constitute the bulk of many other deglacial sequences related to continent-scale ice sheet recessions, as evidenced in post-Late Glacial Maximum (LGM) successions (e.g. Syvitski \& Hein, 1991; Hansen, 2004; Fraser et al., 2005; Corner, 2006; Eilertsen et al., 2011; Nutz et al., 2014, 2015; Normandeau et al.,

6 2015) and in the deep time glacial record (e.g. Proust \& Deynoux, 1990; Ghienne, 2003; Le Heron et al., 2006, 2011, 2013; Isbell et al., 2008; Loi et al., 2010; Girard et al., 2015). The nature and mode of deposition of such deglacial sedimentary sequences are controlled by complex interactions between the history of ice margin retreat (e.g. slow, punctuated, rapid retreat) and evolution of the related sediment entry points, the inherited basin physiography and paraglacial reworking processes, among others (Syvitski \& Farrow, 1983; Brookfield \& Martini, 1999; Lønne et al., 2001; Powell \& Cooper, 2002; Lajeunesse \& Allard, 2002; Occhietti, 2007; Storms et al., 2012; Hein et al., 2014). Across large segments of formerly glaciated inner shelves, rates (up to $10 \mathrm{~cm} \cdot$ year $^{-1}$ ) and amplitudes (>100 m) of the glacio-isostatic rebound significantly outpace those of the eustatic sea-level rise throughout the entire deglacial period (Boulton, 1990). It therefore results in the uplift of deglacial sedimentary successions, which were themselves deposited under conditions of relative sea-level (RSL) fall (e.g. Hart \& Long, 1996; Lajeunesse \& Allard, 2002; Dionne \& Occhietti, 1996; Dionne et al., 2004; Eilertsen et al., 2011; Nutz et al., 2015). The imprints of such an overall forced regressive context have to be formally understood. Forbes \& Syvitski (1994) and Normandeau et al. (2015) stressed that the inland extent of river drainage basins is of prime importance in the stratigraphic development of deltas tied to deglacial sequences.

Depositional systems built after the LGM offer widely datable sedimentary archives and demonstrative connections having a well-preserved morphosedimentary record. The present study takes advantage of an uplifted, Pleistocene to Holocene ( $c a 12500$ to 4000 year BP) deglacial sedimentary complex built on the Québec North Shore and includes ice-contact, in-valley and open-coast deltaic and shallow marine deposits (St. Lawrence Estuary, Fig. 1). The outstanding exposure $(80 \mathrm{~m}$ high and $7 \mathrm{~km}$ long, Fig. 2) enables the following: (i) detailed documentation of internal stratigraphic architectures and the related depositional facies; (ii) proposal of a detailed chronostratigraphic framework; and (iii) deciphering of the relative influence and signatures of forcing factors that controlled the deposition patterns throughout the forced regressive deglacial development. It is postulated here that the resulting scheme may help in unravelling the deep time deglaciation record, for which no dating at a resolution higher than $100 \mathrm{kyr}$ can be expected, in spite of glacial tempos most likely comparable to that of the Late Cenozoic (Pazos, 2002; Fielding et al., 2008b; Ghienne et al., 2014). This study will also show that no river incision occurred during most of the deglacial sequence, corroborating some recent models depicting sediment accumulation during RSL fall conditions (Swenson \& Muto, 2007; Blum et al., 2013; Prince \& Burgess, 2013). 

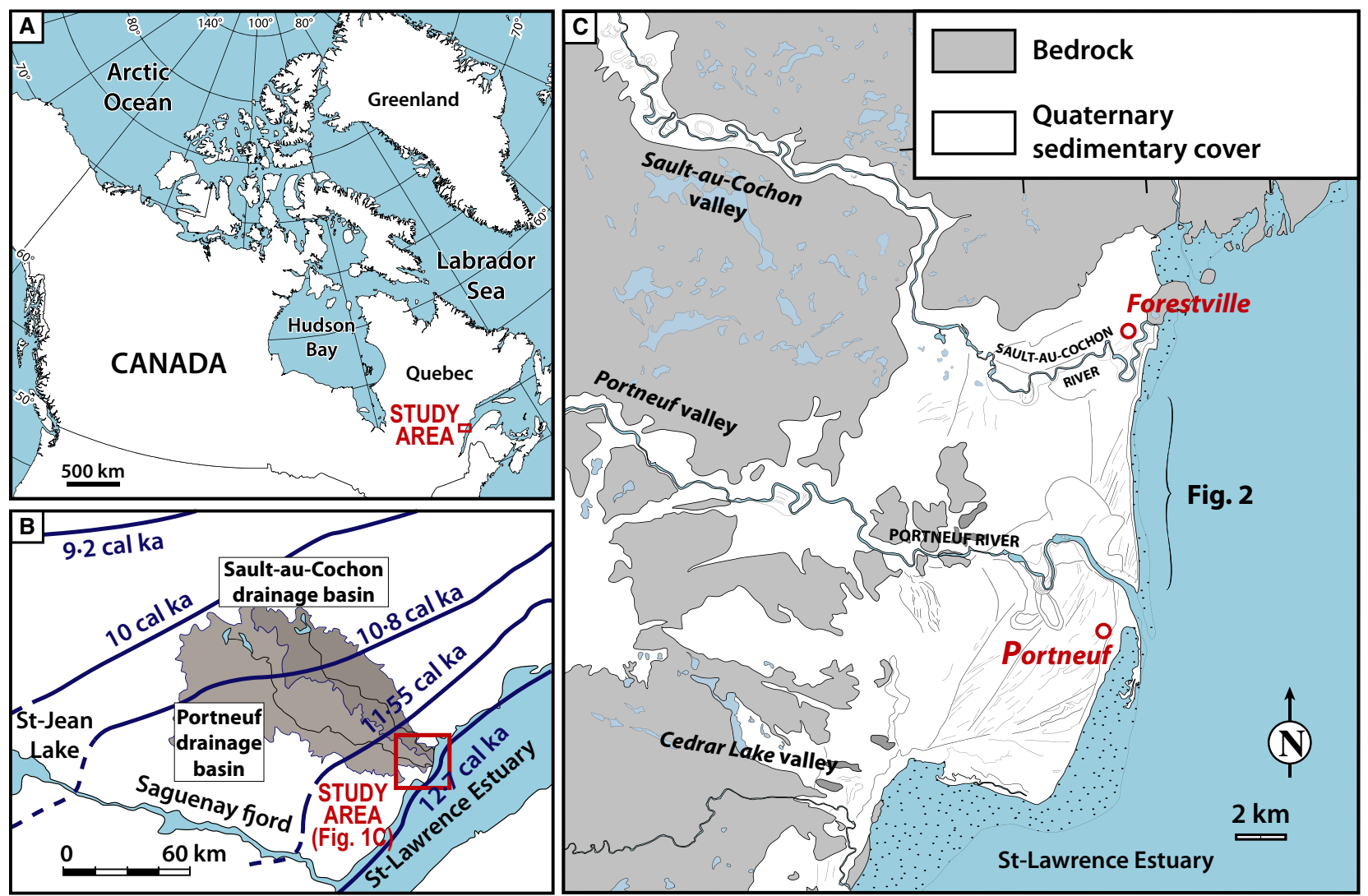

Fig. 1. (A) Location of the study area (B) in the St. Lawrence Estuary. (B) The drainage basins of the Portneuf (light grey) and Sault-au-Cochon (dark grey) rivers, relative to the reconstructed, post-LGM, retreating ice fronts of the Laurentian Ice Sheet (Occhietti et al., 2011). (C) Outline of the Portneuf Peninsula (a detailed version of this map in given in Figure S1).

\section{REGIONAL SETTING}

\section{Geological setting}

The study area comprised the Portneuf Peninsula and its hinterland, which together cover $c a$ $200 \mathrm{~km}^{2}$ on the northern coast of the St. Lawrence Estuary (Québec North Shore, Fig. 1). To the west, Proterozoic basement rocks of the Grenville Province (Thériault et al., 2012) crop out across a gently sloped plateau area at $c a 300 \mathrm{~m}$ elevation. Seawards, only bedrock foothills emerge from the coastal Late Wisconsinan to Holocene sedimentary wedge, the upper surface of which runs from the $c a 140$ m.a.s.l.(above sea-level) elevation down to the present-day shoreline. This surface displays relatively wellpreserved fluvial and marine terraces (Dionne et al., 2004). The sediment wedge thickness is highly variable depending on the underlying bedrock topography. Coastal erosion and river incision have severely cross-cut the sedimentary wedge, and exposures reaching $90 \mathrm{~m}$ in height are distributed along riverbanks and sea cliffs (Fig. 2). Offshore, a shallow coastal shelf extends down to depths of $100 \mathrm{~m}$. At $c a 8.5 \mathrm{~km}$ off the present-day shoreline, a south-west-/north-eastoriented break-in-slope makes an abrupt transition with the St. Lawrence rift system and trough (Tremblay et al., 2003, 2013; Duchesne et al., 2007,2010 ), where the basement top lies at a depth of $700 \mathrm{~m}$.

Onshore, bedrock terrain frequently displays preserved glacial striations, grooves and crescentic chattermarks (Figure S1); bedrock morphologies being thus viewed as inherited relief forms. In addition, deep, steep-flanked and narrow structural valleys are deeply cut into basement rocks, which focus the flow of the Portneuf and Sault-au-Cochon rivers. The depth of the bedrock incisions, which may locally include a basal sedimentary infill underneath the presentday river bed, is unknown. At times, the width and depth of the Portneuf and Sault-au-Cochon 


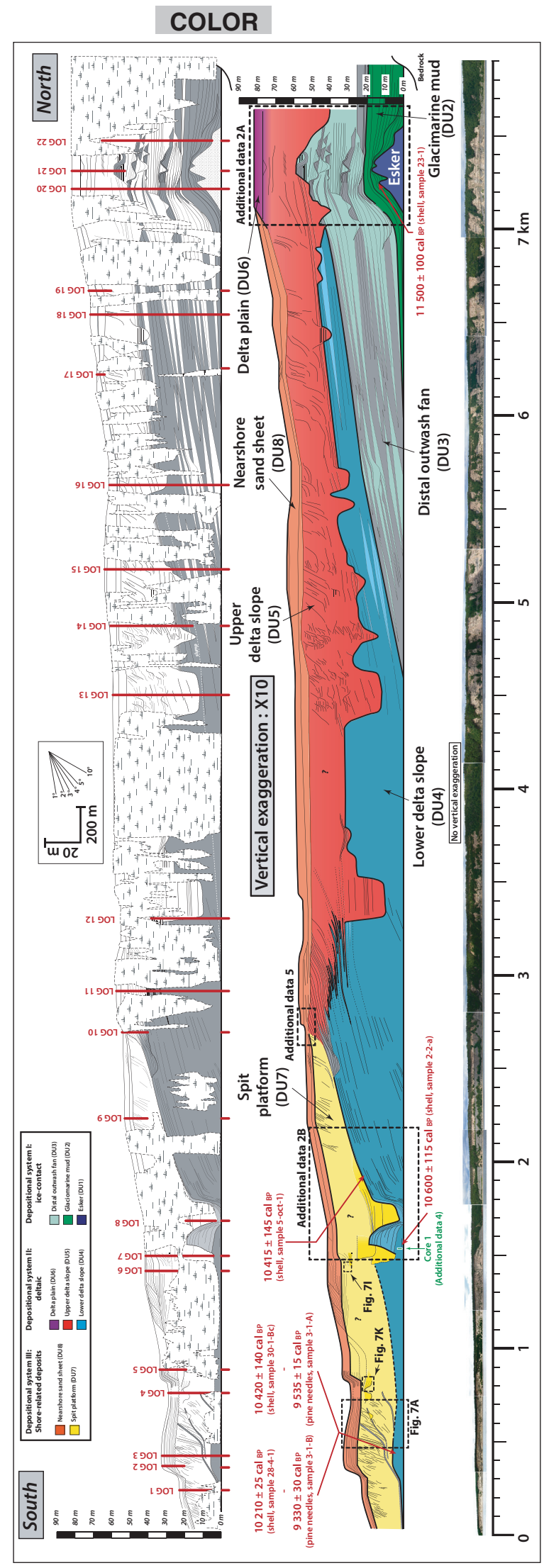

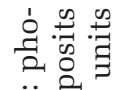

응웡 줄

邑

ㅇ. ․ㅠ 웡

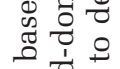

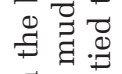

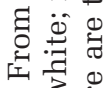

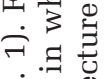

舟空:

.. 윰

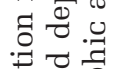

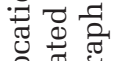

范

궁

क⿺辶一兀

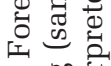

‥ 先.

节密寻

घ.

赵寻

즈웡ํ

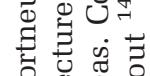

苛总范

$\Xi$ 귱 웡

동.

o 0 究

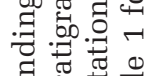

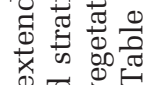

艺

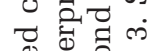

荧.

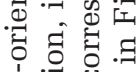

平矛过

잉 80

ट्व

का त

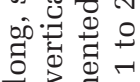

그요요

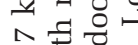

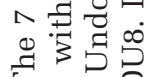

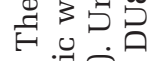

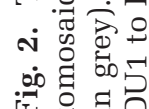




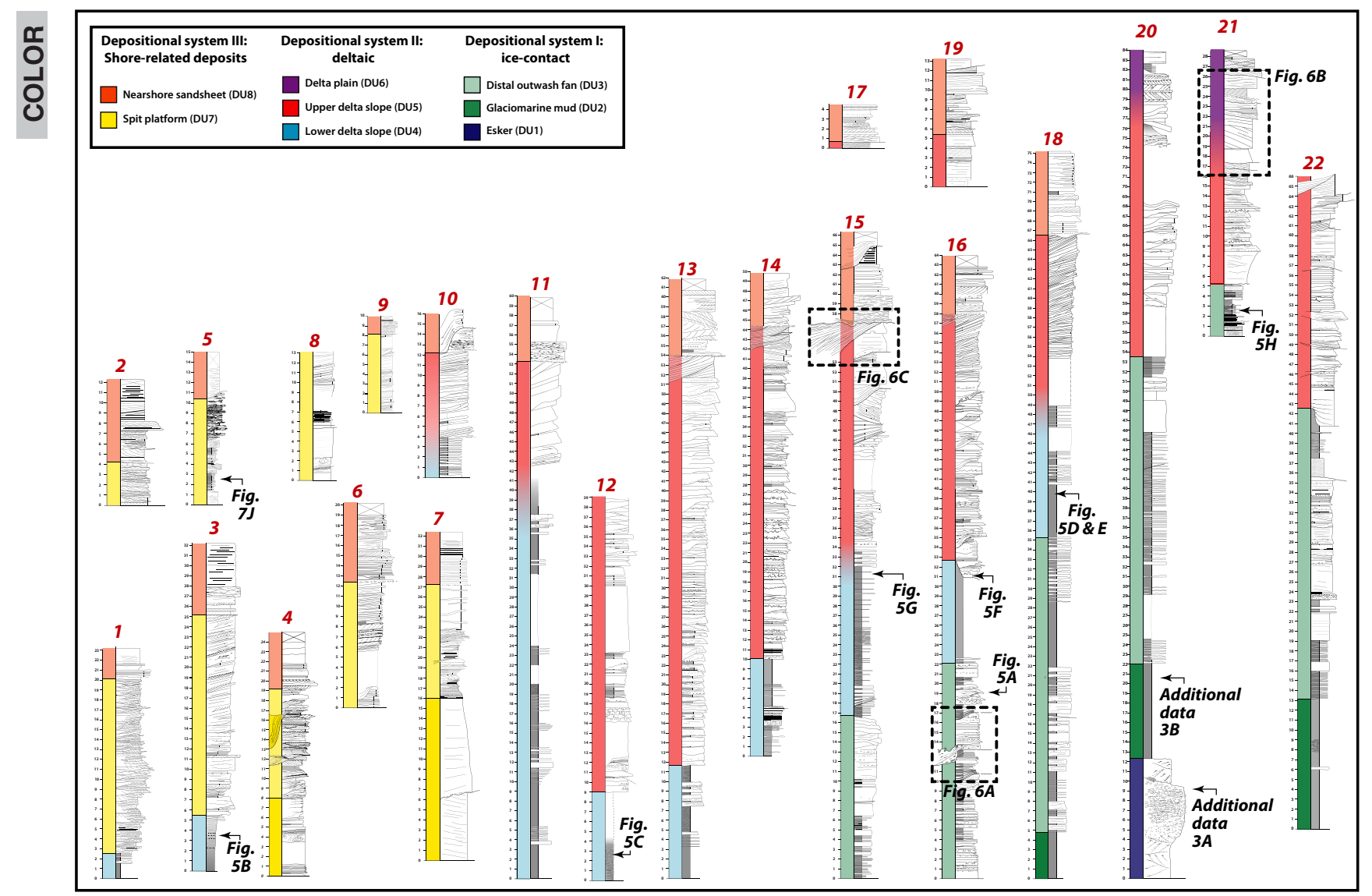

Fig. 3. Sedimentological logs distributed along the cliff (locations in Fig. 2).

valleys are $c a 1 \mathrm{~km}$ and 100 to $150 \mathrm{~m}$, and 0.5 to $0.8 \mathrm{~km}$ and $80 \mathrm{~m}$, respectively. Drainage areas extend $120 \mathrm{~km}$ to the north-west (Fig. 1B). Bedrock thresholds suggest that the structural valley depths may not be significantly greater than the observed flank heights with the possible exception of inner gorges (Lajeunesse, 2014). Marine sediments preserved in terraces along the lower reaches of the valleys lying below 140 m.a.s.l. (marine limit) indicate that they were initially inundated at an early time of deglaciation and were temporarily shallow fjords.

\section{Deglacial setting}

The development of the Portneuf-Forestville deltaic complex dates back to the Laurentide Ice Sheet (LIS) retreat following the LGM. An initial and rapid glacimarine phase of ice margin retreat is interpreted to have occurred across the whole of the St. Lawrence Gulf and Estuary up to the Late Wisconsinan (Shaw et al., 2006). Then, the ice-marginal zones temporarily stabilized along the Canadian Shield highlands bordering the Québec North Shore (Dyke et al., 2002; Shaw et al., 2002, 2006; Occhietti, 2007; Occhietti et al., 2011; Margold et al., 2015; Lajeunesse, in press). After this stage, ablation-dominated continental ice fronts characterized the recession of the Quebec Ice Dome up to its final withdrawal dated at ca 6 kyr (Clark et al., 2000; Storrar et al., 2014). In the St. Lawrence Estuary and Gulf, the resulting depositional sequence consisting of a discontinuous subglacial till covered with ice-proximal to ice-distal glacimarine deposits is ubiquitously draped by 20 to $50 \mathrm{~m}$ of post-glacial hemipelagic muds (Syvitski \& Praeg, 1989; Josenhans \& Lehman, 1999; Duchesne et al., 2007, 2010; St-Onge et al., 2008). The post-glacial marine invasion accompanying the retreat of the LIS margin flooded a glacio-isostatically depressed strip of land (Goldthwait Sea, Occhietti et al., 2004), over which proglacial and paraglacial coastal landforms and deposits developed (Dionne \& Occhietti, 1996; Hart \& Long, 1996; Dionne et al., 2004). The coeval glacio-isostatic rebound led to a regional and continuous RSL fall in spite of the concurrent 
global glacio-eustatic rise (Peltier \& Fairbanks, 2006). As a consequence, a significant part of the growth of the Late Wisconsinan to Holocene sedimentary wedges occurred within a forced regressive context (Hart \& Long, 1996), under high rates of sea-level fall $\left(>2 \mathrm{~cm} \cdot \mathrm{year}^{-1}\right.$, Shaw et al., 2002; Tarasov et al., 2012). According to regional ice-front reconstructions, the Portneuf area was free of ice shortly after $12 \cdot 7 \mathrm{kyr}$ cal BP (Occhietti et al., 2011; Fig. 1B) and the marine limit - the elevation of the highest marine sediments deposited in the Goldthwait Sea - is here estimated to 140 m.a.s.l. (Dionne et al., 2004).

The resulting deltaic complexes have been investigated by onshore or offshore studies in several areas of the St Lawrence Estuary and Gulf (e.g. Natashquan: Long et al., 1989; Sala \& Long, 1989; Sept-Îles: Dredge, 1983; Norman-

14 deau et al., 2013; Boyer-Villemaire et al., 2013; Betsiamites and Manicouagan-Outardes: Bernatchez, 2003; Hart \& Long, 1996; Portneuf: Dionne et al., 2004; Tadoussac: Dionne, 1996; Dionne \& Occhietti, 1996). A recent overview of the subaqueous expressions of the deltaic systems in the St. Lawrence Estuary is given by Normandeau et al. (2015) who conclude that at present day, they are essentially inactive.

\section{Present-day shorelines}

Development of the Portneuf Peninsula since the Mid-Holocene has been dominated by relatively low rates of RSL fall $\left(<1 \mathrm{~cm} \cdot \mathrm{year}^{-1}\right.$, Shaw et al., 2002). The southward-oriented longshore drift nourishes southward-prograding shorelines with a correlative migration of barrier islands and back barrier marshes developed since 4000 years cal BP (Dionne et al., 2004; Fig. 1C and Figure S1). In contrast, the northern Portneuf Peninsula is today experiencing active shoreline

15 retreat (Bernatchez \& Dubois, 2004). As a consequence, the sedimentary complex is intersected in its northern portion by a $>7 \mathrm{~km}$ long, remarkably linear, active cliff extending between Pointe-des-Fortins and Patte-de-Lièvre Island
(Figure S1), the main data provider for this study (Fig. 2).

\section{METHODS}

The geomorphological context is provided by maps of surficial deposits (Fig. 2 of Dionne et al., 2004; Cousineau et al., 2014). The nature, elevation and pattern of landforms were characterized from aerial photographs $(1: 40$ 000, available at the Ministry of Natural Resources and Wildlife, Government of Québec) and satellite images (Google Earth $^{\mathrm{TM}}$ ) combined with the SRTM3 DEM (grid resolution: $93 \mathrm{~m}$, available on the USGS website). Geographic information system (GIS) software was used to account for the effects of glacio-isostatic flexure and rebound (see Leverington et al., 2002) on the basis of isobase curves taken from Shaw et al. (2002) and Tarasov et al. (2012).

The internal architecture of the deltaic complex was analysed from a panoramic photomosaic of the cliff taken from a boat at a distance of $c a 400 \mathrm{~m}$ (Fig. 2 and Figure S2). Regularly spaced sedimentary logs at the 1:100 scale were performed including sedimentary facies description (Fig. 3), with inspection of bounding surfaces observed in the photomosaic. Additional photomosaics and sections were made inland along riverbanks. The inland sections characterize the inner (and older) portions of the deltaic complex (Figs 1 and 4, Figure S1). Six handmade 30 to $40 \mathrm{~cm}$ long cores were recovered in mud facies for the identification of internal structures by X-ray imagery.

Thirteen radiocarbon age determinations were performed at the ${ }^{14} \mathrm{C}$ measurement laboratory of the CNRS (Gif-sur-Yvette, Artemis program/ CNRS-INSU) and at the Poznan Radiocarbon Laboratory (Table 1). Data calibration was performed using the IntCal09 procedure (Reimer et al., 2009). An estimate of the reservoir effect in the St. Lawrence Estuary at the time of the Goldthwait Sea derives from measuring ${ }^{14} \mathrm{C}$ ages of shells and conifer needles in nearby horizons.

Fig. 4. Synoptic transects from the hinterland to the current shoreline, integrating sedimentological logs and morphosedimentary features. (A) In the Cedars Lake valley, the outwash fan (apex at 140 m.a.s.l.) is reworked by marine terraces. (B) The Portneuf Valley transect illustrates the relationship between the basement and the sediment wedge. The delta was initiated as an in-valley fjord head delta before prograding as an open-coast delta. (C) The transect in the interfluve domain highlights the architecture from the proximal to distal outwash fan, superimposed by the proglacial delta. Both are exposed along the cliff (Figure S2A). (D) The Sault-au-Cochon transect includes the in-valley moraine-dammed lacustrine delta, an antecedent outwash fan positioned at the valley outlet (Figure S1) and the subsequent proglacial deltaic system. 


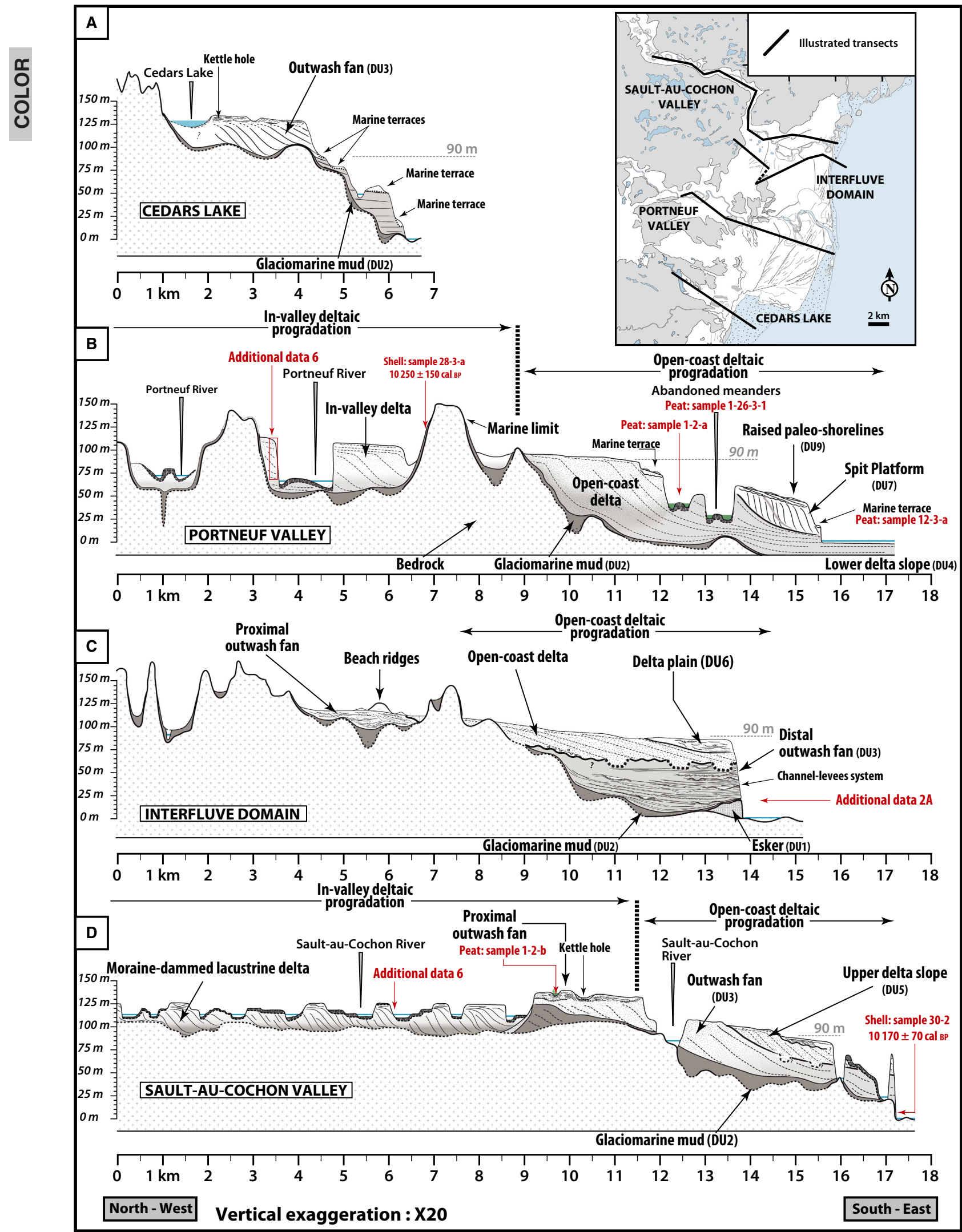




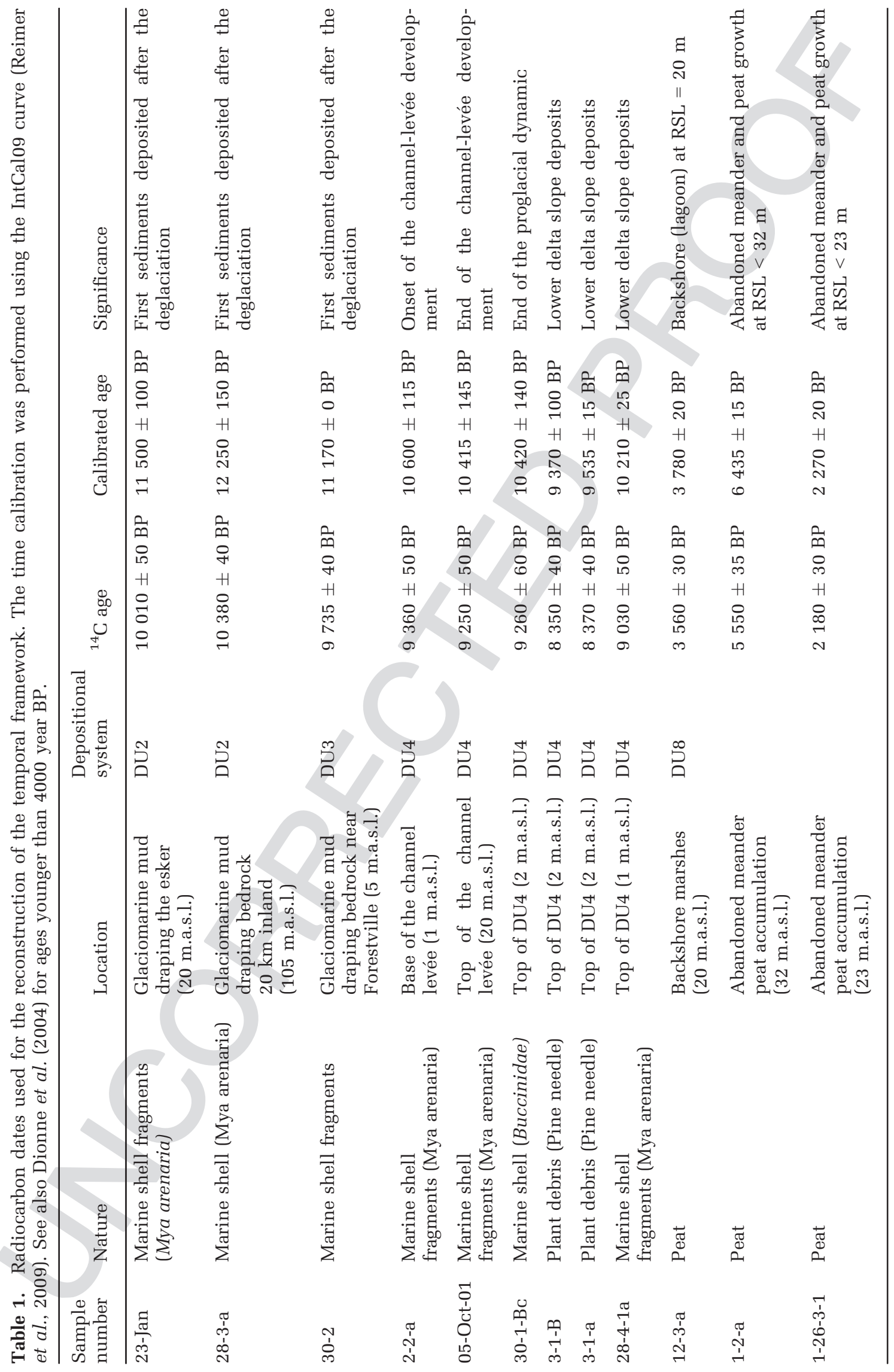


An estimate of $800 \pm 100$ year age difference is determined, which is similar to the reservoir age of the North Atlantic during the Younger Dryas Event (Bard et al., 1994).

\section{LANDFORMS}

An outline of landforms in the Portneuf Peninsula is given below, offering valuable information for the facies interpretation of the underlying deposits observable within the cliff (Fig. 2). A succession of downstepping depositional surfaces separated by break slopes is evidenced from $140 \mathrm{~m}$ (i.e. marine limit) down to the current shoreline. A significant break-inslope is observed around 90 m.a.s.l., marking the transition from upward slopes in the 0.1 to $0.4 \%$ range, to steeper slopes ( 1 to $2 \%$ ) downward. Four types of landforms are identified: fluvial terraces and abandoned meanders, delta plain, ice-contact and coastal forms.

\section{Fluvial terraces and incised, abandoned meanders}

Extensive portions of the Portneuf and the Sault-au-Cochon rivers are meandering and display abandoned meanders and oxbow lakes as well as fluvial terraces (Fig. 1; Figure S1). Incised, abandoned meanders and fluvial terraces are mainly observed at a short $(<8 \mathrm{~km})$ distance from the present-day river mouths, cutting into the coastal sedimentary wedge. Four abandoned meanders are delineated along the lower Portneuf River (Fig. 1; Figure S1). From the older to the younger, they are positioned at decreasing elevations $(65 \mathrm{~m}, 32 \mathrm{~m}, 23 \mathrm{~m}$ and $15 \mathrm{~m})$. Peat accumulation in abandoned meanders at $32 \mathrm{~m}$ and 23 m.a.s.l. provided minimum ages of $6435 \pm 15$ and $2270 \pm 20$ year cal BP (Table 1) for their abandonment, respectively. Abandoned meanders along the Sault-au-Cochon River are staged from 60 to 20 m (Figure S1).

Today, the occurrence of local base levels imposed by bedrock thresholds drastically reduces river incision rates. However, because no bedrock thresholds occur seaward of the abandoned meanders, the related river profiles were adjusted to the regional base level (St. Lawrence Estuary). As shown by meander development along the lower reaches of some of present-day rivers of the Québec North Shore, coastal meanders have elevations very close to the concurrent sea level. Palaeomeander elevations in the study area thus provide valuable (misfit $<5 \mathrm{~m}$ ) estimates of former sea levels at the time of incision.

\section{Delta plain landforms}

Dionne et al. (2004) interpreted the flat sedimentary plain located upslope of the $90 \mathrm{~m}$ elevation contour as deltaic sand. Relic braided channel morphologies in the 90 to $110 \mathrm{~m}$ elevation range are preserved off the outlet of the Portneuf Valley to the south of the current river course. Similar features are also observed north of Forestville (Figure S1). Throughout the delta plain, braided streams have significantly reworked any former coastal landforms and related deposits (see below).

\section{Ice-contact landforms}

Two bodies of ice-contact sediments are identified in the study area (Cousineau et al., 2014). The main body (Fig. 4; Figure S1) crops out at the Sault-au-Cochon Valley outlet. It consists of a large fan-shaped sediment accumulation reaching 5 to $7 \mathrm{~km}$ in width. Its apex is located at the narrowest point of the valley outlet. Radiating to the south-east, its upper surface is even and subhorizontal near the apex that is positioned at 140 m.a.s.l. (i.e. marine limit). It progressively slopes down, reaching $110 \mathrm{~m}$.a.s.l. at $5 \mathrm{~km}$ to the south. The upper surface of the ice-contact sediment body shows subdued relict channels and subcircular to elongated, topographic depressions, 20 to $50 \mathrm{~m}$ in diameter, occupied by lakes or peat bogs (relict kettles). A subordinate body of ice-contact sediments is identified in the Cedars Lake valley (Figure S1).

The flat-topped and fan-shaped ice-contact bodies were emplaced during the retreat of the LIS margin (Cousineau et al., 2014). The occurrence of kettles indicates an ice-marginal outwash setting in front of glacier snouts debouching from valleys. With their subaqueous, more ice-distal counterparts cropping out downslope along the current shore (see below, 'DU3' and Fig. 2), they provide evidence of outwash fan systems larger than the relatively restricted ice-contact deposits observed in map view. It is worth noting that comparable deposits do not exist off the outlet of the Portneuf Valley.

\section{Coastal landforms}

Two generations of coastal structures have been observed. The first generation is observed above 
90 m.a.s.l. and only includes sparse forms on the delta plain or bordering the ice-contact sediment bodies. Over the delta plain, a SSW-NNEoriented, $3 \mathrm{~km}$ long and $50 \mathrm{~m}$ wide sand ridge is preserved below 110 m.a.s.l., halfway between the Portneuf and the Sault-au-Cochon rivers (Fig. 1; Figure S1). On both sides, it is bordered by subordinate sand ridges. Arcuate sand ridges are also identified over the original palaeodepositional profile of the ice-contact deposits, from its apex (140 m.a.s.l.) to nearly 110 m.a.s.l. (Figure S1). All of these sand ridges are interpreted as relict raised beach ridges, palaeocliffs, spits, cusps and tombolos reworking outwash or delta plain sands.

The second generation of coastal landforms is identified below the break-in-slope at 90 m.a.s.l. It consists of well-defined, extensive, linear landforms organized in a succession of flats and scarps. Scarps can be traced over the entire surface of the deltaic complex. The longest and highest scarp-oriented SSW-NNE extends along $17 \mathrm{~km}$ between Milles-Vaches Bay and Forestville (Figure S1). Its upper limit coincides with the $90 \mathrm{~m}$ break-in-slope and its height decreases northwards from $25 \mathrm{~m}$ to $5 \mathrm{~m}$ (Fig. 1; Figure S1). Four other, less-expressed, downstepping scarps are observed at lower elevations. Progressive change in their azimuth (SSW-NNE to SW-NE) causes truncation by the current cliff development, thereby offering exposed sections (Fig. 2). In flats between two successive scarps, sand ridges and intervening swales are 50 to $200 \mathrm{~m}$ in wavelength, 1 to $3 \mathrm{~m}$ in height. Beach ridges and sand spits were separated by back barrier marshes (Dionne et al., 2004). The overall configuration reflects alternating phases of coastal erosion and beach accretion, for which it is difficult to assess the relative contribution of autocyclic processes - for example, nearby river mouth avulsion, Dominguez (1996) or cyclic formation patterns tied to finite sediment sources

17 (Hein et al., 2014) - or of allogenic forcing such as millennial climatic cycles (e.g. Sorrel et al., 2012). Coastal landforms are intimately associated with an underlying sand sheet of nearshore deposits.

\section{STRATIGRAPHIC ARCHITECTURES AND DEPOSITIONAL FACIES}

In the cliff exposure, eight depositional units (DU1 to DU8) characteristic of eight depositional environments are distinguished by their stratal patterns and facies associations (Fig. 2). Facies associations encompass the 18 lithofacies summarized in Table 2. Information related to radiocarbon dating is summarized in Table 1. Sample locations are given in Figs 2 and 4. Depositional units are described from bottom to top, that is from the oldest and/or deepest to the youngest and/or shallowest (forced regressive setting). For sake of clarity, the eight depositional units are grouped into three depositional systems: (i) icecontact (DU1 to DU3); (ii) open-coast deltaic (DU4 to DU6); and (iii) coastal (DU7 and DU8). In the following, notations such as ' $\mathrm{km} \mathrm{2}$ ' or ' $\mathrm{km}$ 2 to 3 ' refer to positions along the cross-section shown in Figure 2 (origin at the southern tip of the cliff). An in-valley deltaic depositional system is described, which is not cropping out in the cliff but in the hinterland.

The entire region is characterized by continuous glacio-isostatic rebound with decreasing rates from the early phase of deglaciation up to the present day (Tarasov et al., 2012; Peltier et al., 2015). Thus, considering that the upper part of the cliff is characterized by coastal landforms, for example raised beaches, the minimal depositional palaeobathymetry for any underlying deposits is the height range up to the upright cliff top. The value is a minimum estimate because: (i) the erosional surface located at the base of the nearshore sand sheet inherently includes a hiatus (see below) and (ii) a depositional unit within the cliff is not strictly coeval with the beach deposits immediately above but relates to a shoreline positioned higher and landward.

\section{Depositional system I: Ice-contact deposits}

\section{Depositional unit 1: Esker}

Description. Depositional unit 1 (DU1) rests directly on the striated bedrock cropping out on Patte-de-Lièvre Island (Fig. 2, km $7 \cdot 0$ to $7 \cdot 5$ ) where it forms an upwardly convex lenticular body of about $500 \mathrm{~m}$ in width and at least $18 \mathrm{~m}$ in thickness, having an irregular upper bounding surface (Fig. 2; Figure S2A). Depositional unit 1 lies immediately beneath distal glacimarine muds (DU2).

Depositional unit 1 consists of poorly stratified sand and pebbles. Medium-grained to coarsegrained sand with faint oblique lamination (SGr2, Table 2) prevails. Well-rounded clast-supported pebbles (C1, Figure S3A) constitute metrethick conglomeratic beds. A few decimetre-scale intraclasts of cohesive silty sands are observed. 


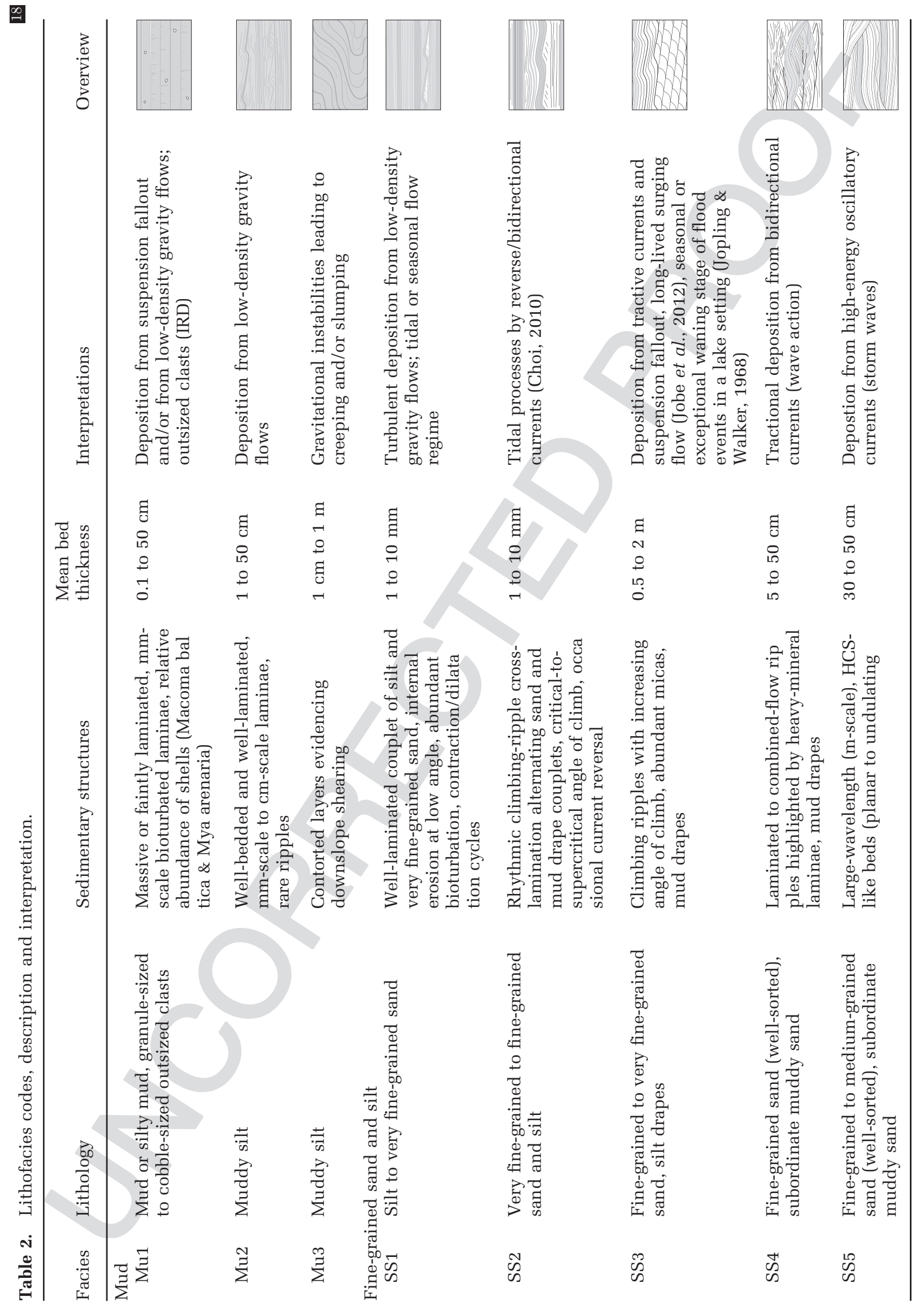




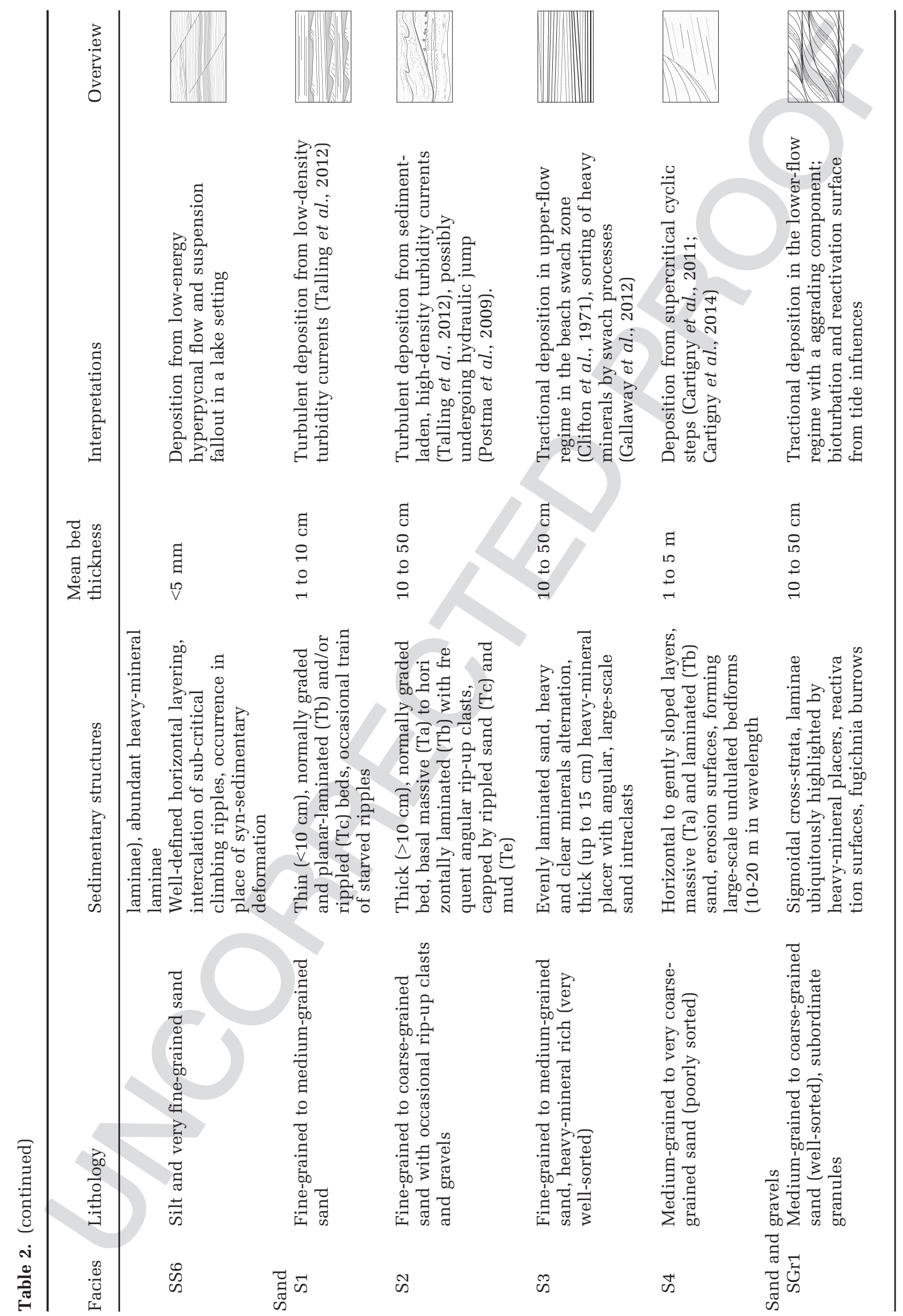




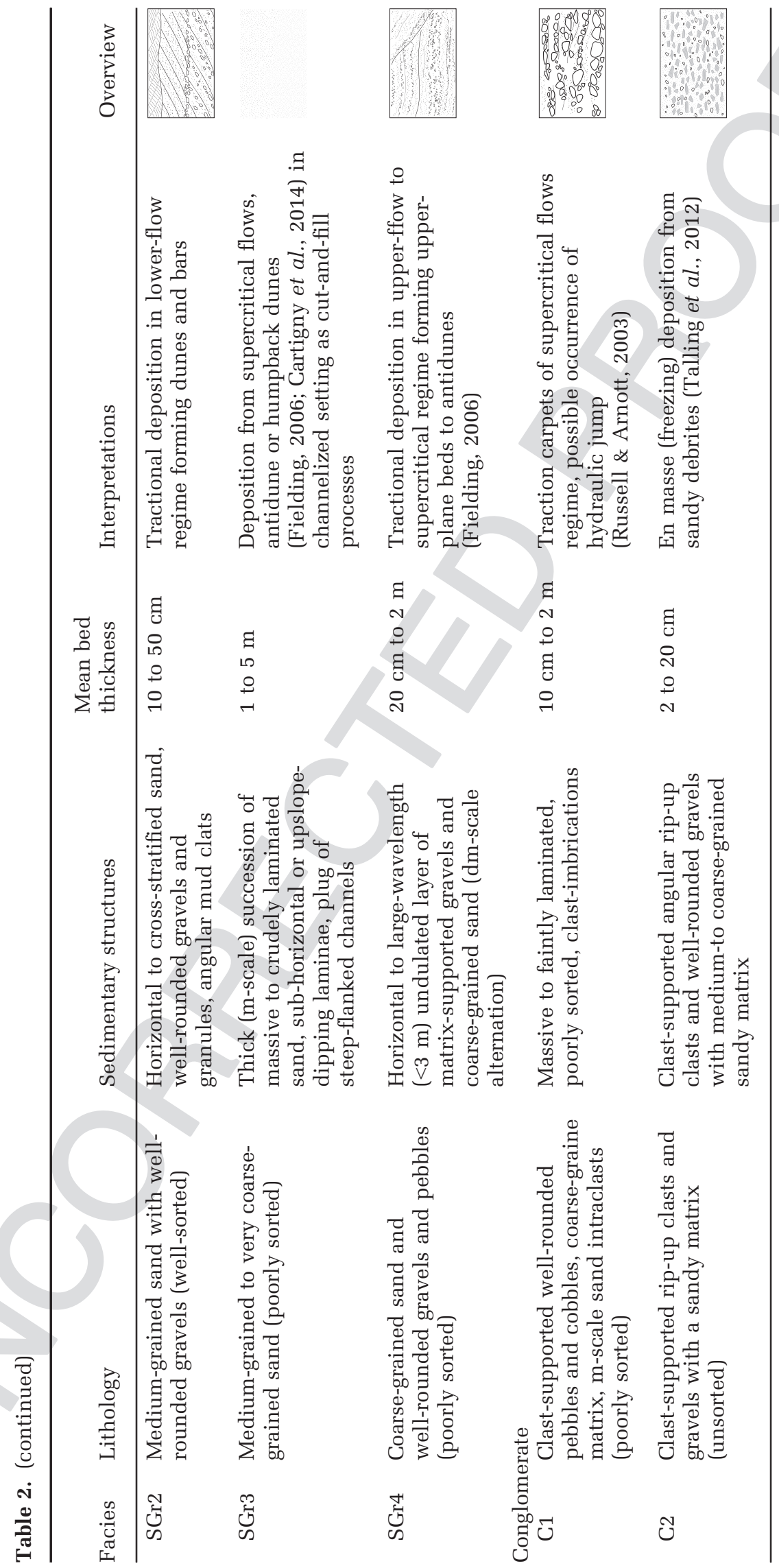


Pebble imbrications and cross-stratal dips indicate N150-oriented palaeoflows.

Interpretation. The stratigraphic position of DU1 just above the glacially abraded bedrock and beneath distal glacimarine muds, as well as its lenticular geometry, indicates that it originated as an esker. Conglomeratic deposits, faint laminations and sand intraclasts together suggest a high-energy depositional system tied to hydraulic jump processes (Russell \& Arnott, 2003; Cummings et al., 2011).

\section{Depositional Unit 2: Glaciomarine mud}

Description. Depositional unit 2 (DU2) is identified from $\mathrm{km} 6$ to the northern end of the profile. Depositional unit 2 overlies the esker, and its minimal thickness is $4 \mathrm{~m}$ over the esker crest. It thickens laterally to reach a maximal thickness of $12 \mathrm{~m}$. Mud beds show both onlap onto the esker body and internal onlap relationships (Fig. 2; Figure S2A). The upper bounding surface of DU2 is conformably overlain by DU3.

Depositional unit 2 consists of faintly laminated and bioturbated muds (Mu1) with scattered granule to cobble-sized lonestones. The bedding is, in places, highlighted by rare thin $(<1 \mathrm{~cm})$ sand layers (S1). Reworked shells (Macoma baltica) are relatively abundant (Table 1).

Interpretation. Lonestones, representing icerafted debris (IRD), and faint laminations, indicating deposition by settling processes from overlying turbid plumes, are indicative of glaciomarine mud. Thickness changes over the inherited esker topography as well as internal unconformities suggest subordinate bottom currents. The rarity of large IRD, the intense bioturbation and the sparse presence of thin sand layer interpreted as turbiditic beds suggest an ice-distal depositional environment (Boulton, 1990; Ó Cofaigh \& Dowdeswell, 2001).
Depositional Unit 3: Outwash fan

Description. Depositional unit 3 (DU3) is recognized in the northern half of the cross-section, where it forms a significant part of the cliff (Fig. 2). It conformably overlies DU2 and corresponds to a wedge-shaped body that reaches $40 \mathrm{~m}$ in thickness. To the north, the upper bounding surface of DU3 is a truncation surface (base of DU5), while southwards it corresponds to a conformable contact below DU4 (Fig. 2). To the north ( $\mathrm{km} 6.8$ to $7 \cdot 6)$, the stratal pattern is dominated by the occurrence of extensive mud-rich heterolithic sheets (Figure S2A) interstratified with numerous channel structures and subordinate sand sheets. Southwards $(\mathrm{km} 4.5$ to 6.8), channel structures are absent. Instead, gently sloped heterolithic sheets alternate with sand sheets. Both have an average slope of 1.05 to $1.4 \%$ (Fig. 2).

Heterolithic sheets are mud-rich and well-stratified deposits including thin sand layers. Distinct internal facies distributions are identified in the lower and upper part of DU3. Well-laminated and occasionally bioturbated mud intervals (Mu2, 5 to $10 \mathrm{~cm}$ ) and rippled sand layers (S1) prevail in the lower part (Fig. 5A). In the upper part, heterolithic sheets are coarser grained. The finest fraction consists of silt to very fine-grained sand facies (SS1). In places, rhythmites with contraction-dilation cycles are observed (Fig. 5F). Interstratified sand layers are more specifically characterized by trains of starved ripples (S1; Fig. 5H). Sand sheets consist of amalgamated normally graded sand beds (S2) with frequent liquefaction structures and rip-up clasts.

Channel structures are 10 to $200 \mathrm{~m}$ wide, up to $5 \mathrm{~m}$ deep incisions cutting in the heterolithic sheets. Each is characterized by a basal, 0.5 to $2.0 \mathrm{~m}$ thick, draping heterolithic unit (Mu2 or SS1), while the main infill corresponds to a sandy (S1 and S2) plug (Fig. 6A) directly onlapping the channel

Fig. 5. Depositional facies from the distal outwash (DU3) to the upper delta slope (DU5, see location in Fig. 3). (A) Normally graded turbiditic sand bed (facies S2) in the distal outwash fan (DU3) with the following subdivisions above a basal erosive surface: $\mathrm{T}_{\mathrm{a}}$ (massive, with lithic and angular mud clasts); $\mathrm{T}_{\mathrm{b}}$ (subhorizontal lamination) grain-size break; $\mathrm{T}_{\mathrm{C}}$ (ripples); and $\mathrm{T}_{\mathrm{e}}$ (mud drape) intervals. (B) Shell debris and a lonestone (dropstone) in massive to laminated mud (Mu1) in the lower delta slope (DU4). (C) Laminated mud (Mu2) underlying a thick (>1 m) contorted muddy layer (Mu3) that was used as marker bed in Fig. 2. (D) Lower delta slope (DU4) facies showing alternating sand-sized (S1) and finer-grained deposits (Mu2, SS1). Details in the following images: (E) and (F) rhythmic climbing ripples (RCRL structure) in SS1 facies; note double-mud couplets and lee-side accretion of the sand fraction (E) and contraction-dilatation cycles (F). (G) Sharp transition (base of a U-shaped trough) between the lower and upper delta slope (DU4 and DU5). (H) Well-laminated very fine-grained sand and silt including couplets and contraction-dilatation cycles (SS1) in distal outwash fan deposits. Note the train of starved ripples. 

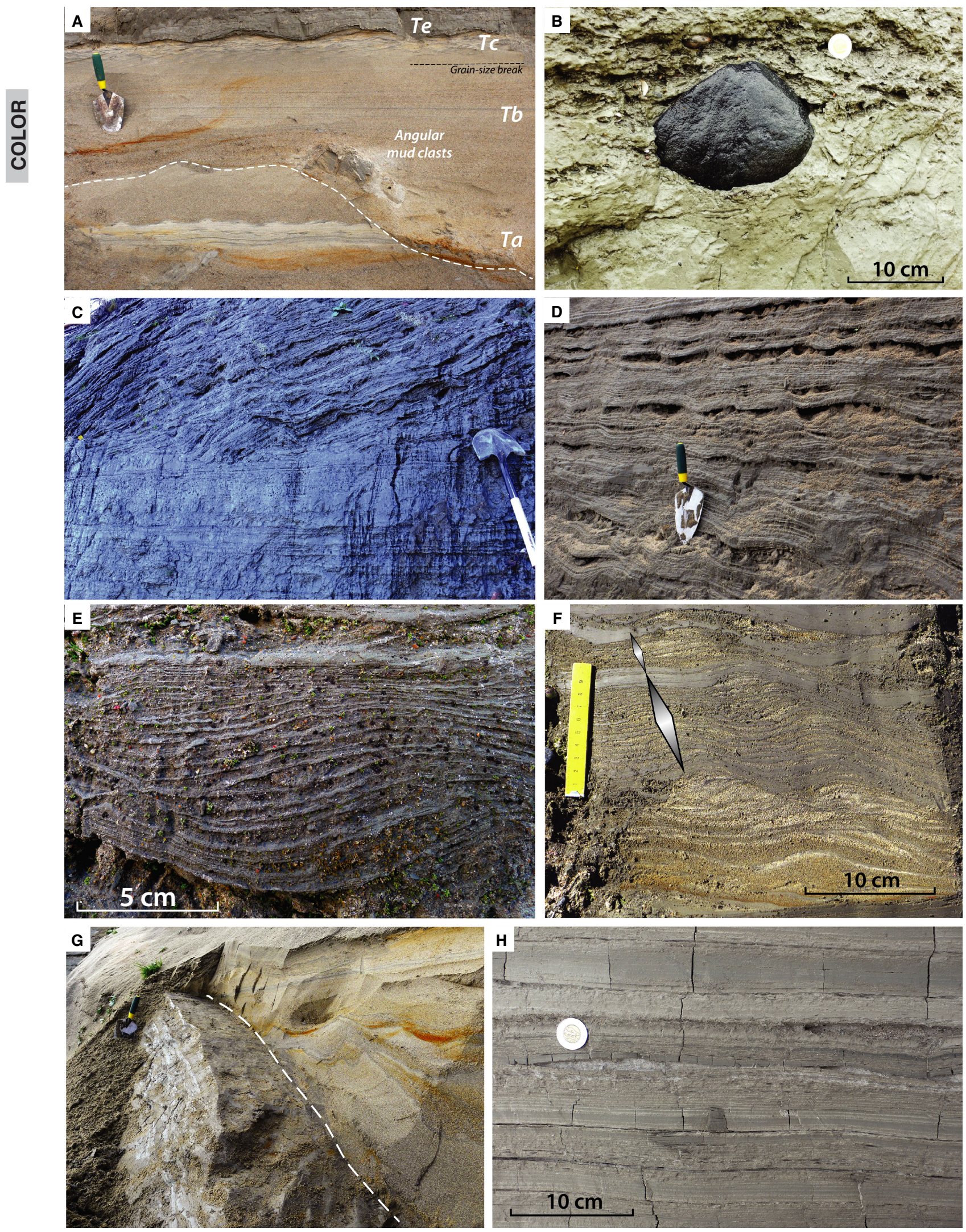

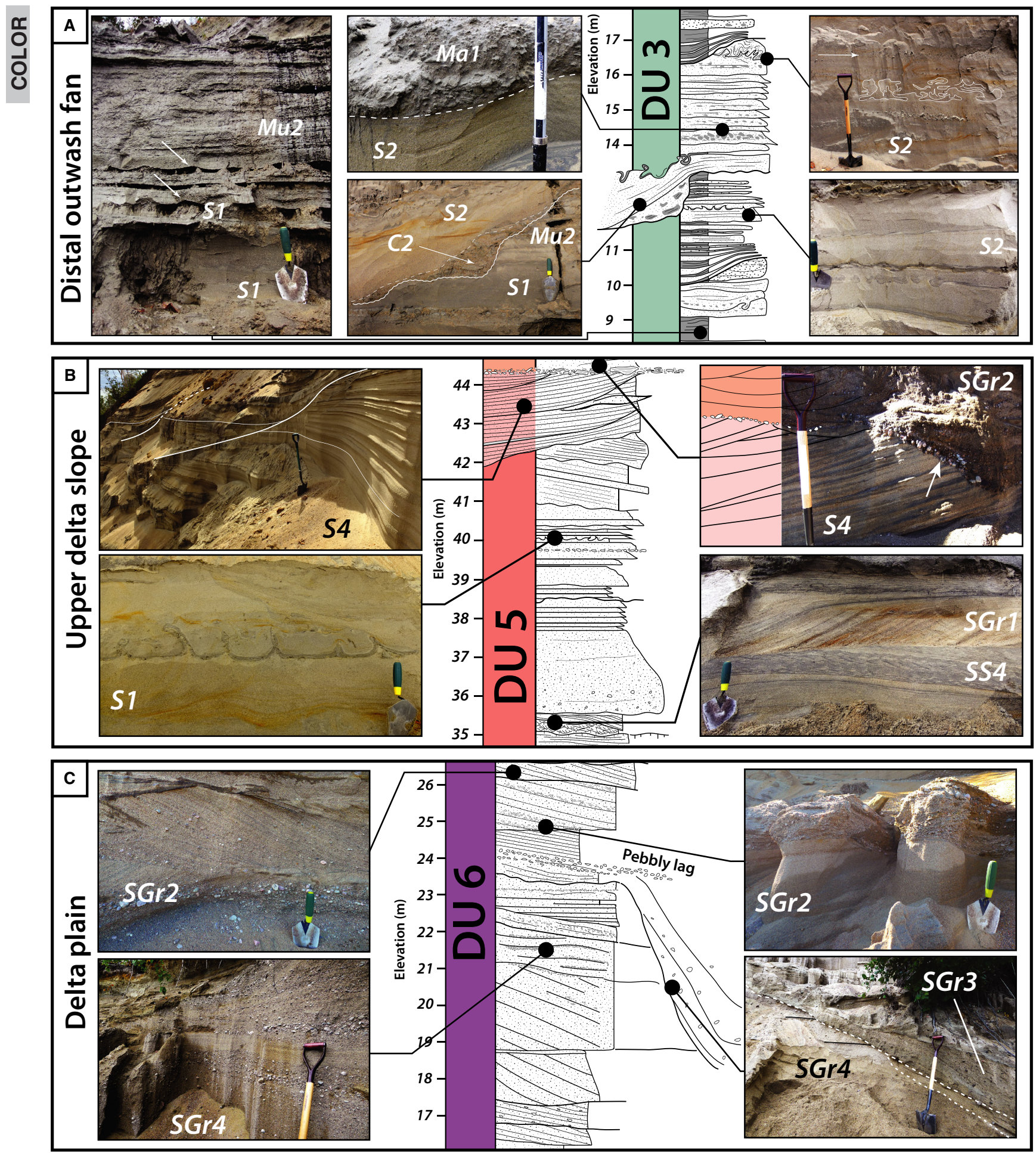

Fig. 6. Facies associations representative of the distal outwash fan (DU3) (A), the upper delta slope (DU5) (B) and the delta plain (DU6) (C). See Fig. 3 for stratigraphic position and Table 2 for facies codes.

flanks. Sandy channel plugs of some steepflanked scours, $50 \mathrm{~cm}$ in depth and several metres in width, consist of normally graded sands showing in places a mixture of immature rip-up clasts and granules (Ma1). In places, mud clasts are demonstrably derived from the immediate adjacent eroded mud beds (Figs 5A and 6A). 
Interpretation. Along the subaqueous segment of the outwash fan (i.e. the cliff exposure), and in contrast to the underlying glaciomarine muds, DU3 is notably devoid of IRD. It indicates the demise of the glacimarine depositional system and suggests that the glacimarine ice front turned into a continental front (e.g. Lønne, 1995; Lønne \& Nemec, 2004). Depositional channel and sheet geometries and depositional facies together conform to a turbiditic system (Table 2). The number and the limited size of the channels suggest a network of relatively small channels rather than a trunk channel. Sand sheets represent lobe deposition, while heterolithic sheets interfingered with either channel or lobe deposits represent interchannel to interlobe deposits. A channel distribution limited to the north and prevailing gently sloped sand sheets downslope to the south suggest a channel-lobe transition. The topography inherited from the esker, an expression of which was maintained during the deposition of DU3 (Fig. 2), controlled at least in part the position of this channel-lobe transition. Autocyclic avulsions in the active channel-lobe complexes probably resulted in the alternation through time of heterolithic sheets and channels, as well as sand and heterolithic sheets, upslope and downslope, respectively. Similar high-density turbiditic facies (S2) observed in both sand sheets (lobes) and channels suggest that some of the channels were plugged by backstepping lobe deposits (e.g. Turmel et al., 2015). Narrow scours including mud clasts of very local origin suggest hydraulic jump processes in agreement with depositional conditions at the channel-lobe transitions (Garcia \& Parker, 1989; Kostic \& Parker, 2006; Postma et al., 2009; Postma \& Cartigny,

23 2014). Heterolithic sheets were formed by the incremental accretion of low-density turbidites likely originating from overspilling and/or stripping flows (e.g. Fildani et al., 2006; Kane et al., 2010).

The outwash fan deposits present in the cliff are inferred to be the distal counterpart of the fan-shaped depositional system recognized at the outlet of the Sault-au-Cochon Valley at 140 m.a.s.l. (Cousineau et al., 2014; Figure S1). Here, ice-contact landforms (see above) and conglomerates (C1) including boulders and sand intraclasts suggest flow deconfinement processes at the outlet of a subglacial conduit over a subaerial or shallow outwash plain (Cutler et al., 2002; Russell et al., 2009) overhanging the downslope finer-grained subaqueous outwash fan; depositional depths of the latter range from 140 to $80 \mathrm{~m}$.

\section{Depositional system II: Open sea deltaic deposits}

There is a demonstrably depositional continuum from DU4 to DU6. An upslope facies transition along clinoform geometries is particularly well-expressed from DU4 to DU5 (Fig. 2; km 3.2 to $2 \cdot 4$ ), the latter being the proximal counterpart of the former. More upstream, a transition from DU5 to DU6 does exist, but is expressed less clearly. This depositional system is thus understood as a suite of depositional environments distributed along deltaic clinoforms running from the delta plain (DU6) down to the lower delta slope (DU4). The elevation difference between the lowest visible deposits of DU4 and the highest deposits of DU6 is $90 \mathrm{~m}$ (Fig. 2). It provides a minimal estimate for the vertical development of the deltaic clinoforms.

\section{Depositional Unit 4: Lower delta slope}

Description. Depositional unit 4 (DU4) constitutes a major component of the cross-section extending throughout most of the cliff (Fig. 2), but it is a subvertical and poorly accessible portion of the cross-section (Figure S2). Depositional unit 4 consists of a relatively thick $(<40 \mathrm{~m})$ wedge of mud-rich heterolithic facies including some subordinate metre-thick sand units. Its lower bounding surface is conformable on the underlying distal outwash fan deposits. Depositional unit 4 pinches out to the north as it is truncated by DU5 (upper delta slope). Southwards, its upper bounding surface appears as a composite contact (Fig. 2): from $\mathrm{km} 7 \cdot 0$ to $3 \cdot 2$, U-shaped troughs (Fig. 5F) alternate with paraconformable portions; from $\mathrm{km} 3 \cdot 2$ to $2 \cdot 4$, lateral facies transitions develop along clinoforms (Figs 2 and 5G). A large-scale well-defined channel-levée structure is observed from $\mathrm{km} 1.4$ to $2 \cdot 1$ (Fig. 2).

Heterolithic deposits consist of horizontally laminated mud (Mu2) and sand layers (S1) (Fig. 5D). Sand occurs as millimetre to centimetre-thick beds of continuous or starved ripple trains. From $\mathrm{km} 4$ to 7 , relatively sand-rich heterolithic beds include rhythmic climbing-ripple cross-lamination (RCRL, sensu Choi, 2010) in several metre-thick, uninterrupted, depositional successions (SS2, Fig. 5D and E). Occasional contorted intervals are observed (Mu3), the 
thickest $(1 \mathrm{~m})$ being used as a marker bed (Figs 2 and 5C). Interstratified sand units consist of amalgamations of 10 to $30 \mathrm{~cm}$ thick normally graded sand beds (S2).

The channel-levée structure, $20 \mathrm{~m}$ deep in the thalweg axis (Fig. 2; Figure S2B), forms an asymmetrical feature, including a well-defined levée to the south that bears beds dipping towards the channel axis (Figure S2b). The opposite flank is formed by descending strata constituting the bulk of DU4. In the levée deposits, the relative amount of sand - essentially contained in starved ripple trains flowing away from the channel axis - rapidly decreases away from the thalweg. X-ray imagery (Figure S4) shows inverse and normal grading in the vertical stacking of millimetre to centimetre-scale mud laminae.

At the southern tip of the cliff, the outcropping portion of DU4 is only $3 \mathrm{~m}$ thick. In the lower portion, faintly laminated mud (Mu1) contains abundant shells, plant debris (wood fragments and pine needles) and some gravel to pebble-sized lonestones (Fig. 5B). The upper portion shows intensively bioturbated deposits including an increasing proportion of normally graded sand (S1) interstratified with laminated muds (Mu2).

Interpretation. Mud-dominated deposits, gently sloped depositional geometries (dips $<3^{\circ}$ ) beneath and beyond the sandier deposits of DU5, indicate that DU4 encompasses lower delta slope sediments. Older DU4 horizons at the base of the cliff were penecontemporaneous of a delta plain not exposed in the cross-section - at an elevation comprised between $90 \mathrm{~m}$ and 140 m.a.s.l. - while the upper horizons were penecontemporaneous with delta plain deposits constitutive of DU6. The minimal depositional bathymetry was in the 30 to $90 \mathrm{~m}$ depth range.

Deposition from low-density turbidity currents (Mu2, S1) prevailed. Occasional subordinate deposition from high-density turbidity currents occurred that splayed from the upper delta slope (DU5) over the lower delta slope forming turbiditic lobes. The RCRL suggests a tidal influence in spite of the relatively deep depositional bathymetry. Fluviotidal interactions in mouth environments (Gilbert, 1983; Cowan et al., 1998;

25 Ayranci et al., 2012), the influence of internal tides (Pomar et al., 2012; see Saucier \& Chassé, 2000; Bourgault et al., 2014; Normandeau et al., 2014 for internal tides in the St. Lawrence
Estuary) or daily discharges cycles in meltwater flows may form structures very similar to the RCRL, which are usually recognized in intertidal environments (Choi, 2010).

In addition to the relatively unconfined turbidites interpreted above, the channel-levée structure provides evidence for the occurrence of a confined sediment pathway. The position and the asymmetry of the channel-levée suggest a meandering channel (Babonneau et al., 2010) at the base of delta slope, near a transition with prodelta environments. Inverse and normal grading in heterolithic levée deposits (Figure S2) suggests river-derived hyperpycnal flows (Mulder \& Syvitski, 1995). Levée accretion, including sand layers without in-channel sand aggradation, indicates the bypass of sandy turbidity flows. Beds dipping towards the thalweg axis relate to inner levée, sensu Kane et al. (2007). Radiocarbon dating (Fig. 2; Figure S2B) shows that a significant portion of the channel-levée structure was built in 100 to 200 years. The basinward prolongation of such a channel is preserved as a buried channel on the Laurentian Shelf (Normandeau et al., 2015; their fig. 9).

To the south, faintly laminated mud (Mu1), intensive bioturbation, limited sand deposition and reduced aggradation rates (ca $0.6 \mathrm{~cm} \cdot \mathrm{year}^{-1}$ inferred from radiocarbon dating, Fig. 2) in distal DU5 deposits indicate prodelta environments. Whether lonestones (Fig. 5B) were derived from sea ice or from icebergs calved in adjacent areas (e.g. the mouth of the Saguenay Fjord, Fig. 1B) remains unclear, their apparent relative abundance being preferentially interpreted as the result of reduced aggradation rates.

\section{Depositional Unit 5: Upper delta slope} Description. Depositional Unit 5 (DU5) composes the most important sand wedge of the cross-section with a mean thickness of $30 \mathrm{~m}$. Its lower bounding surface on DU4 is marked by Ushaped troughs up to $20 \mathrm{~m}$ in depth and $250 \mathrm{~m}$ in width (e.g. $\mathrm{km} 3.4$ and $\mathrm{km} \mathrm{4.5),} \mathrm{which} \mathrm{alter-}$ nate with conformable segments (Fig. 2). A clear facies transition ( $\mathrm{km} 2.5$ to 3.3 ) is observed from DU4 to DU5. The upper bounding surface of DU5 is a well-defined truncation surface corresponding to the base of DU8 (nearshore sand sheet).

Depositional unit 5 consists of offlapping sand-rich clinothems. The infill of basal Ushaped troughs consists of horizontal to gently sloped beds $\left(<1^{\circ}\right)$ onlapping on trough flanks. They correspond to the lower segments of the 
clinothems (e.g. km 4.5). Upslope, clinoforms locally include small-scale internal channel-like incisions (10 to $20 \mathrm{~m}$ wide, 3 to $5 \mathrm{~m}$ deep). Their dips progressively increase up to $6^{\circ}$, reaching in places $17^{\circ}(\mathrm{km} \mathrm{6 \cdot 3})$. Small-scale geometries similar in appearance to secondorder clinoforms, but that show internal intricate onlapping patterns, are observed in the uppermost part of the cliff $(\mathrm{km} 4.5$ to $7 \cdot 2$; Fig. 6B).

From the base to the top, a gradation in depositional facies is observed in DU5 (Fig. 3). The infill of the basal U-shaped troughs consists of vertically stacked, up to $50 \mathrm{~cm}$ thick, normally graded sand beds (S2) and occasional debrite beds (Ma1). Both beds include abundant angular mud clasts and well-rounded lithic granules. These beds generally show facies sequences limited to a superposition of massive and laminated subdivisions (top cut-out turbidites). Upwards and above the trough interfluves, sand beds progressively thin and contain less abundant lithic clasts; debrite beds became rare then absent. From the middle of the cliff up to $15 \mathrm{~m}$ beneath the basal truncation of DU8, sand beds coarsen and thicken upwards, reaching one metre in thickness. Meanwhile, mean stratal dips increase upwards to clinoform dips (6 to $17^{\circ}$ ). Sand beds contain an increasing upwards proportion of well-rounded gravels, and their basal surfaces show progressively better defined scour structures. Bioturbated intervals of rippled finegrained sand (SS4) associated with sigmoidal cross-strata (SGr1) are locally interbedded (Fig. 6B). The uppermost part of DU5 includes channelized backsets overlain by low-angle cross-strata backstepping against southward-dipping, regularly spaced (ca $10 \mathrm{~m}$ ), concave-up erosion surfaces with 'pseudo-clinoform' geometry. While backsets consist of massive to faintly laminated gravelly sands (SGr3), backstepping strata consist of a stack of massive to laminated decimetre-thick sand beds including subordinate layers of muddy sand (S4) (Figs 3 and 6B).

Interpretation. Based on well-defined clinoform geometries (Fig. 2), DU5 is interpreted as being upper delta slope deposits. Considering that DU6 (delta plain) is more or less coeval with the youngest DU5 and DU4 strata (see DU4), depositional bathymetries for DU5 are in the 20 to $60 \mathrm{~m}$ range, reaching $80 \mathrm{~m}$ regarding the lowermost infill of the U-shaped troughs. As shown by decreasing dip of strata from the top to the base of DU5, the delta slope depositional profile was concave-up, passing downslope asymptotically to the mud-dominated deposits of DU4.

Normally graded and laterally continuous sand beds observed throughout DU5 are interpreted as turbiditic beds, essentially unconfined above the U-shaped troughs. The infill of the Ushaped troughs resulted from confined turbidity flows that underwent hydraulic jump processes as indicated by massive and/or faintly laminated intervals (Postma et al., 2009). The association of rounded lithic and angular mud clasts indicates that these deposits mixed far-travelled sediments and clasts of local origin, the latter resulting from the excavation of surrounding beds. Upwards, and in interfluves of U-shaped troughs, deposition was tied to high-density turbidity currents. A progressive increase in sediment concentration and flow competence is indicated by the coarsening-upward trend, the increasing content in lithic clasts and better developed basal scours. The intervening bioturbated sigmoidal cross-strata were probably emplaced during a short-lived interval of predominant tidal processes during deltaic accretion.

The U-shaped troughs are interpreted as having been formed at the break-in-slope marking the transition between the upper and lower delta slope. These U-shaped troughs may have been formed by turbidity flows experiencing hydraulic jumps due to slope reduction (e.g. Massari \& Parea, 1990; Breda et al., 2007; Gobo et al., 2014). Pseudo-clinoform geometries and channelized backsets observed at the top of DU5 typify cyclic step deposits (Cartigny et al., 2011; Postma \& Cartigny, 2014; Dietrich et al., 2016).

In the upper delta slope, the unconfined turbiditic beds along the upper part of the clinothems contrast with deposits infilling U-shaped troughs. Unconfined deposition is thought to reflect background sedimentation when sands were essentially deposited by sheet-like turbiditic flow events. Background sedimentation was interrupted episodically by high-energy events characterized by more dynamic events forming channelized conduits along the delta slope. The channelized conduits were possibly connected downslope to a channel-levée structure similar to that described in DU4 and/or to sandy depositional lobes identified in the lower delta slope (see DU4).

\section{Depositional Unit 6: Delta plain}

Description. Depositional unit 6 (DU6) is identified at the top and northernmost part of the 
cliff ( $\mathrm{km} 7 \cdot 0$ to $7 \cdot 5)$, immediately upstream of, and above DU5 (Figs 2 and 4A; Figure S2A). It consists of a 15 to $20 \mathrm{~m}$ thick wedge showing subhorizontal bedding. The basal contact with the underlying upper delta slope is transitional in terms of its depositional facies. The upper surface of DU6 defines the flat top of the cliff at 90 m.a.s.l. Depositional unit 6 extends to the north under the forest cover. It pinches out southwards over a short distance $(\mathrm{km} \quad 7)$. Although the contact with DU8 does not crop out, a truncation surface at the base of the nearshore sand sheet is most likely.

Two vertically superimposed coarse-grained facies assemblages comprise DU6. The lower facies, $5 \mathrm{~m}$ in thickness, consists of thick $(>1 \mathrm{~m})$, erosion-based, subhorizontal beds of gravelly sands (SGr4) (Fig. 6C). Bed contacts and laminations show undulations, 5 to $10 \mathrm{~m}$ in wavelength. Internal erosion surfaces define poorly circumscribed steeply flanked scours filled by massive to faintly laminated gravelly sand (SGr3). The upper facies assemblage, truncating the underlying one along a subhorizontal surface underlined by pebbly lags, consists of a fining-upward and thinning-upward succession of coarse-grained, cross-stratified sand beds (SGr2) (Fig. 3). Coarse-grained, planar cross-stratified sands containing abundant well-rounded gravels and pebbles pass upwards into lenses of medium-grained planar cross-stratified sands interbedded with thin $(<20 \mathrm{~cm})$ and laterally discontinuous mud layers. Rare decimetre-scale, angular mud clasts are scattered within crossstratified sand. Palaeocurrent measurements indicate both westward and eastward flows.

Interpretation. The facies transition from the underlying steeply sloped clinothems (DU5) to subhorizontal stratal patterns indicates that DU6 represents the correlative delta plain, which was separated from the delta slope by a topographic break-in-slope (delta brink) reflected by the drastic change in dip patterns. Large undulations in the lower facies assemblage of DU6 strongly suggest supercritical flows conditions (Fielding, 2006). In contrast, the upper facies assemblage related to bedload processes formed in relatively low-energy environments. A fluvial-dominated setting is inferred for DU6 as relict braided channels observed in plan view (Figure S1), although not effectively connected to DU6, offer the map view expression of such delta plain environments. However, a tide-influenced setting is also suggested by current reversals.

The vertically superimposed lower and upper facies assemblages relate to spatially juxtaposed depositional environments, which are ascribed here to a subtidal and intertidal delta plain, respectively. The change from a subcritical to supercritical hydraulic regime from the intertidal to subtidal delta plain requires a parameter that allows the kinetic energy of the flow to increase downstream in the absence of slope increase. A 'tidal drawdown' process, acting as a flush during ebb tide (Smith et al., 1990; Dietrich et al., 2016), may explain such a paradoxical transition. The channel structure filled by SGr3 facies (Fig. 6C) probably breached the delta brink, feeding directly the upper delta slope.

\section{Depositional system III: Coastal deposits}

The third depositional system is comprised of DU7 and DU8. Depositional unit 8 forms a laterally continuous sand sheet at the top of the cliff, atop of which are the coastal landforms described above (Fig. 1; Figure S1). Successively truncating DU6, DU5 and DU7 from north to south, it is a diachronous unit following step by

Fig. 7. Architecture and facies of the spit platform and mouth-related deposits (DU7). See Table 2 for facies codes. (A) Photomosaic and line drawing ( $\mathrm{km} 0.4$ to $0 \cdot 7$; location in Fig. 3) highlighting clinoforms and master beds, both dipping to the south. The basal surface of DU7 is ascribed to a diachronous erosion surface (RSME, ravinement surface of marine erosion). The upper part of the cliff corresponds to the nearshore sand sheet (DU8, see also Figure S5); its base is a surf diastem. (B) Bioturbated sigmoidal cross-strata with reactivation surfaces and heavy-mineral laminae. (C) Cross-stratified sands (SGr2) constituting the master beds of the shoreface sand wedge. (D) Palaeocurrents (cross-stratal dips) are almost perpendicular to the master bed dips and almost parallel to inferred orientation of the palaeoshoreline. (E) Escape burrows (fugichnia) and heavy-mineral-rich laminae from tidal bars illustrated in (B) (SGr1). (F) Well-defined, subhorizontal to undulating (hummocky-like) laminations in sands (SS5) and rippled sands (SS4) in storm-related clinoforms. (G) Fine-grained and muddy sands in combinedflow ripples (SS4). (H) Gravel lag at the interface (surf diastem) between DU7 and DU8. (I) Turbiditic sand beds (S1) in aggrading channels and including and oxidized wood debris. (J) Pseudoclimbing ripples in heterolithic facies including currents reversal (SS1). (K) Steep-flanked scour with a massive to faintly laminated coarse-grained infill (SGr3) severely truncating underlying deposits (trowel for scale). 

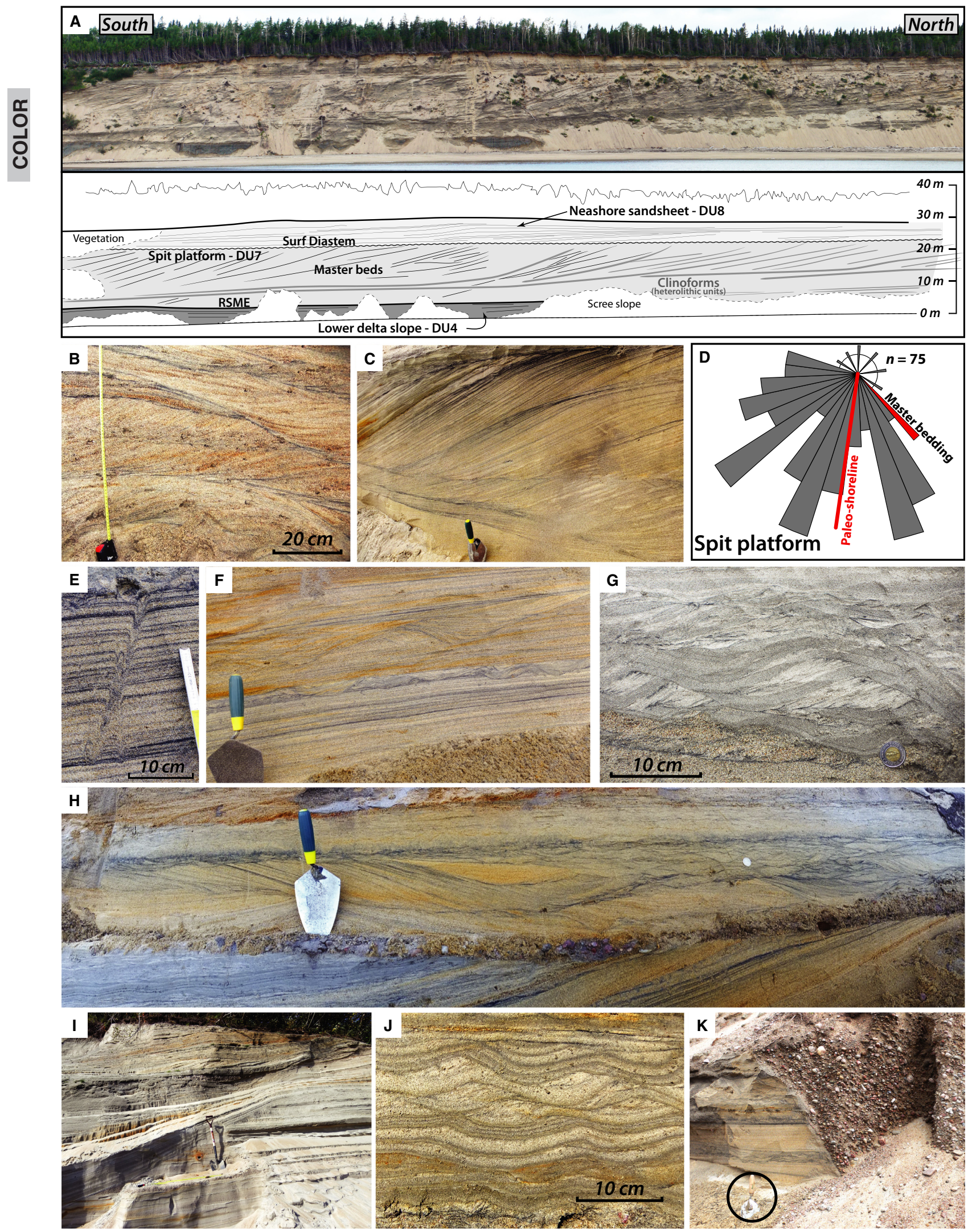
step the falling sea level. In contrast, DU7 only characterizes the lowest and southernmost segment of the cross-section. It represents late deposits coeval with low RSL.

\section{Depositional Unit 7: Spit platform and mouth- related deposits}

Description. Depositional unit 7 (DU7) crops out at the southern tip of the cliff ( $\mathrm{km} 0$ to 2.7; Figs 2 and 7). It forms a well-individualized sand wedge pinching out northwards against DU5. The lower bounding surface is sharp but paraconformable onto prodelta deposits (lower part of DU4). It is truncated by the overlying nearshore sand sheet (DU8). The maximum observable thickness of DU7 is $35 \mathrm{~m}$ (Figs 2 and 7).

Depositional unit 7 mainly shows large-scale clinoform geometries and superimposed smallerscale master beds (Figs 2 and 7A). Gently sloped $\left(<2^{\circ}\right)$ clinoforms that are underlined by 1 to $2 \mathrm{~m}$ thick, distinctively finer-grained deposits truncate steep-sloped (10 to $12^{\circ}$ ), coarse-grained master beds and downlap at the kilometre-scale onto DU4. Some channel structures locally depart from this well-organized clinoform/master bed system (Figs 2 and 7). They form either small-scale 'scour and fill' structures $(\mathrm{km} 0 \cdot 8$, $\mathrm{km} \mathrm{1.5)}$ or the plug of the large channel-levée structure described in DU4.

The bulk of DU7 consists of planar and trough cross-stratified, medium-grained to coarsegrained sands (SGr2, Fig. 7C) that form the steeply dipping master beds. In a few places, crossstrata correspond to metre-scale sigmoidal laminae sets bounded by reactivation surfaces highlighted by thin heavy-mineral laminae (SGr1, Fig. 7C) and burrows (mainly escape structures: fugichnia, Fig. 7E). Dips of cross-strata evidence a wide spectrum of palaeocurrents from the south-east to the north-west (Fig. 7D). A mean trend to the south-west, however, suggests palaeocurrents essentially transverse to the master beds (dipping up to $12^{\circ}$ to the south-east). Draping the basal erosion surface defining each of the clinoforms, associated finer-grained deposits are made up of a specific heterolithic facies assemblage showing an alternation of finegrained rippled sand and muddy drapes (SS4), with HCS-like undulating lamination highlighted by well-defined heavy-mineral-rich stripes (SS5, Fig. 7F).

Scour and fill structures show a variety of grain sizes and internal stratal patterns. At $\mathrm{km}$ $1 \cdot 5$, a large scour is filled by very thick (1 to
$5 \mathrm{~m}$ ) massive to faintly laminated sand beds (SGr3). They are characterized by abundant, decimetre-scale, angular rip-up clasts, which progressively decrease upwards in size and abundance. Above, well-stratified, fine-grained and normally graded sand beds (S1) are genetically linked with smaller-scale scours. Sand beds are 10 to $20 \mathrm{~cm}$ thick, include abundant wood debris (oxidized) and are separated by thin $(<1 \mathrm{~cm})$ mud intervals commonly associated with load and flame structures (Fig. 7I). In places, RCRL (SS2) is interfingered (Fig. 7J). Linked scour structures, $10 \mathrm{~m}$ wide and $3 \mathrm{~m}$ high, truncate the underlying beds but are, however, conformably draped by normally graded beds very similar to those that have been truncated. The basal erosion surface grades laterally into conformable contacts (Fig. 7I). Last, a third type of scour and fill structure is observed at $\mathrm{km}$ 0.7. Here, steep-flanked, very narrow scours (Fig. 2) are filled with pebbly sands, either massively or faintly laminated, including backsets (SGr3, Fig. 7K).

Interpretation. In a coastal setting, cross-strata associated with inclined master beds indicate either the lateral migration of a sandspit system or the frontal accretion of a delta. However, transverse palaeocurrent orientations rather suggest deposition from bars and dunes driven by diffracted longshore currents as evidenced by the distribution of palaeocurrents, conforming to a spit system (Fig. 7D). At the top of the cliff, coastal landforms and the absence of fluvial channels corroborate such an interpretation (Fig. 1; Figure S1). Coarse-grained, bioturbated, sigmoidal cross-strata suggest the influence of tidal processes down to the lower parts of the clinoforms (depositional depth $>15 \mathrm{~m}$ ). More specifically, DU7 is interpreted as a spit platform, sensu Meistrell (1972). A spit platform serves as a basement for a sandspit when the latter is prograding in a relatively deep (i.e. tens of metres) setting (Shaw \& Forbes, 1992; Nielsen \& Johannessen, 2009; Zecchin et al., 2010). In the present case study, it can be argued that the spit platform inception occurred from the point at which the depositional depth, essentially inherited from the depositional profile of the former delta, increased significantly from a few metres to at least $30 \mathrm{~m}$ (Fig. 2, km 2.6). The spit itself (DU8) was then emplaced onto this platform.

The south-westwardly accretion of bars and dunes was recurrently interrupted by erosional 
events resulting in the development of the larger-scale gently sloped clinoforms. Erosion surfaces cut into the shoreface environment, and the overlying occurrence of HCS-like laminations in the draping heterolithic deposits suggest storm events. The downlap surface of the clinoforms is understood as a regressive surface of marine erosion (Plint \& Nummedal, 2000; Catuneanu, 2002; Swift et al., 2003). In this interpretation, DU7 corresponds to the forced regressive shoreface sand wedge of Swift et al. (2003).

Subordinate deposition from gravity flows is identified in the infill of channels and scour and fill structures. Well-stratified and normally graded beds are interpreted as low-density gravity flow deposits derived from hyperpycnal currents. The abundance of terrestrial organic matter debris (Zavala et al., 2010) and the lack of any observed slump scars (Plink-Björklund \& Steel, 2004) together suggest riverine parent outflows. In places, RCRL-like structures (SS1) strongly suggest the influence of tidal processes. Narrow scour structures and the associated massive to faintly laminated deposits, including immature mud clasts and/or backsets, are interpreted as deposits related to hydraulic jump processes (Russell \& Arnott, 2003; Postma \& Cartigny, 2014). In this position, such processes may have eroded DU4 at the depth of $15 \mathrm{~m}$, producing abundant angular mud clasts that were rapidly redeposited.

The restricted lateral extent of channel and scour infills as well as specific grain-size features suggests that gravity flow deposits in DU7 depart from the overall spit platform system. It is interesting that, in map view, channel and scours are located basinward of the large abandoned fluvial meander at 65 m.a.s.l. (Figure S1). Such a palaeogeographic location and depositional facies together suggest that related deposits were genetically linked with former river mouths. The interfingering of facies assemblages demonstrates that spit platform and mouth deposits were essentially coeval, the latter being deposited within localized incisions cut in the spit platform, with a subordinate contribution to the total sediment volume.

\section{Depositional Unit 8: Nearshore sand sheet}

Description. Depositional Unit 8 (DU8) is a laterally extensive sand sheet atop the cliff (Figs 2 and 7A; Figure S5). It continuously runs from $\mathrm{km} 0$ to $7 \cdot 1$ but is absent in the northernmost segment of the cliff at elevations higher than $85 \mathrm{~m}$. Usually, its thickness is 6 to $8 \mathrm{~m}$, but reaches up to $15 \mathrm{~m}$ in some places. The basal bounding surface is a composite truncation surface that shows a suite of stair steps, each connecting with downstepping scarps identified in map view (Figure S1). Individual erosion surfaces are concave upwards, steep-sloped $\left(>15^{\circ}\right)$ in their upper part (Figure S2A). The tangential profile progressively flattens to the south eroding the underlying deposits. The erosion is highlighted by a lag deposit including basement gravels to rare cobbles (Fig. $7 \mathrm{H}$ ). Thus, the basal bounding surface is the juxtaposition of the lower segment of successive, individual concave-upward erosional profiles. The upper bounding surface of DU8 is more or less parallel to its basal bounding surface reproducing the stair morphology.

Depositional unit 8 shows horizontal to subhorizontal bedding. Intermediate, small-scale, gently dipping $\left(<1^{\circ}\right)$ clinoforms are identified in places, downlapping on the composite basal erosion surface. Three facies assemblages are generally distinguished from the base to the top of DU8. The lower facies assemblage consists of trough cross-stratified coarse-grained sand and gravel (SGr2, Fig. 7H). A bimodal palaeocurrent trend is evidenced showing north-eastward and south-westward orientations. In places, laminated to rippled fine-grained sand with heavymineral laminae and bioturbation (escape burrows, SS4) are present. In the middle part of DU8, the facies assemblage consists of wellsorted and well-laminated sand (S3) including metre-scale shallow scours. In places, heavy minerals are distinctively well-segregated, forming placers up to $20 \mathrm{~cm}$ in thickness (Figure S5C). Genetically associated with tangential erosion surfaces, decimetre-scale angular sand intraclasts show evidence of rotational slides (Figure S5B) and thin $(<10 \mathrm{~cm})$ contorted beds. In the upper facies assemblage of DU8, heavy minerals are more diffusely distributed in evenly and monotonously laminated sands (Figure S3D).

Interpretation. Depositional unit 8 deposits are genetically associated with raised beach ridges and associated landforms and thus constitute a nearshore sand sheet. Truncation of progressively younger underlying deposits towards the south, together with decreasing elevation of DU8 deposits, is characteristic of diachronous sedimentation during forced regression and glacio-isostatic rebound deposits (Boulton, 1990; Dionne et al., 2004; Fraser et al., 2005; 
Helland-Hansen \& Hampson, 2009; Hein et al., 2014).

More precisely, the lower facies assemblage represents surf zone deposits (Clifton et al., 1971), emplaced above a surf diastem sensu Swift et al. (2003) (or wave erosion surface sensu Fraser et al., 2005; their fig. 20), which is highlighted at this site by lag deposits. Sediment contribution to shore accretion was probably related to longshore bar migration that may have generated the gently dipping clinoforms. Note that the dips of related structures are only apparent. True dips are expected to be slightly steeper, considering that the cliff intersects the coastal landform suites at an angle of $\mathrm{Ca} 30^{\circ}$ (Figs 1 and 2). The middle facies assemblage represents foreshore sands including swashbackwash laminae (Clifton et al., 1971) and placers (Gallaway et al., 2012). Shallow scours are interpreted as ebb tide rip channels, incised within berms and/or longshore bars. At the top, the upper facies assemblage essentially represents aeolian deposits characterized by the absence of segregation of the heavy minerals.

Internal concave-upward erosional profiles are interpreted as coastal notches (Erikson et al., 2007; Anthony, 2008), that is preserved bluffs subsequently left behind by the overall regressive trend. Oversteepening of the foreshore profiles resulted in gravity slides and/or in the formation of sand intraclasts, suggesting moisture cohesion or frozen sands (Runkel et al., 2010). Although no evidence for the downslope continuation of the concave-upwards erosional profile has been clearly documented owing to subsequent surf diastem erosion, it is tentatively proposed that notches in the foreshore were formerly connected in shoreface environments to the large-scale clinoforms described in DU7 deposits (Fig. 7A). Erosion surfaces extending from the foreshore to the shoreface may relate to particularly severe storm events (Erikson et al., 2007) or to more lengthy periods of enhanced coastal erosion.

\section{In-valley depositional system}

Inland, exposures in the bedrock-confined Portneuf and Sault-au-Cochon valleys do not have the appreciable continuity of the cliff cross-section. Their integration in the stratigraphic framework is, however, crucial for the understanding of the overall deglacial sequence, because they allow the definition of a fourth, in-valley depositional system that records an earlier phase of progradation relative to that documented along the cliff in depositional system II (Fig. 4). The fjord head delta and moraine-dammed lacustrine delta facies associations are recognized in the Portneuf and Sault-au-Cochon valleys, respectively.

\section{Fjord head delta}

Description. In the Portneuf Valley, $15 \mathrm{~km}$ away from the cliff, the present-day river exposes a coarsening-upward, $50 \mathrm{~m}$ succession, at elevations ranging from 60 to $110 \mathrm{~m}$ (Figure S6). Here, three facies assemblages are delineated, successively dominated by mud (lower unit), sand (middle unit) and pebbles (upper unit, Figure S6A).

By comparison with facies associations documented in the cliff cross-section (Fig. 2), the overall succession appears as a variant of the DU4 to DU6 deltaic progradation. The lower unit, $7 \mathrm{~m}$ thick, is primarily composed of thin mud layers (Mu2) interstratified with thin $(<30 \mathrm{~cm})$ intervening sand beds (S1). Up to $1 \mathrm{~m}$ thick, contorted intervals are observed (Mu3, Figure S6F). The middle unit, $40 \mathrm{~m}$ thick, shows a coarsening-upward trend. Its lower portion is similar to the underlying lower unit but includes thick normally graded sand beds (S2) that contain abundant angular mud clasts. Ubiquitous rhythmical stratal patterns are observed (Figure S6D and E). Above, mud intervals disappear and turbiditic sand beds (S2) are stacked together. Bed interfaces ubiquitously show load casts and flame structures. Bioturbation also occurs in places. Syn-sedimentary downstepping extensional fractures are abundant and a several metre-long intraformational shear zone (subhorizontal décollement surface) was identified (Figure S4C). In the upper part of the middle unit, large-scale undulating and normally graded sand beds having a conspicuous rhythmical stratal pattern (S4, Figure S4B) are noted. The upper unit, which has a sharp, erosional contact, is characterized by cross-stratified, well-rounded pebbles.

Interpretation. The lower and middle units echo those deposits already described from the lower and upper delta slope in the sea cliff, respectively. The distinctive, coarse-grained upper unit is interpreted as a fluvial terrace. This inland succession charts the progradation of a fjord head delta prior to progradation in the open sea domain. The lower unit is dominated by low-density turbidity currents and settling from buoyant plumes. The contribution of highdensity turbidity currents increases upward in 
the middle unit reflecting the deltaic progradation. Here, the common occurrence of gravitational instabilities is apparent (step fractures and shear zone), in contrast to the delta slope setting of the cliff cross-section is interpreted as the signature of high rate of sediment accumulation.

\section{Moraine-dammed lacustrine delta}

Description. The moraine-dammed lacustrine delta facies association has been specifically identified within the Sault-au-Cochon Valley (Fig. 4; Figure S1). It was deposited upstream of and after the ice-contact outwash fan (DU3) that initially dammed the outlet of this valley and against which it onlaps.

A coarsening-upward succession is observed. At the base, subhorizontal well-laminated silty fine-grained sand (SS6, Figure S7A) grades upwards into in-phase climbing-ripple laminations (Figure S7B). Upwards, ubiquitous climbing current ripples (SS3) develop; they form gently inclined ( 1 to $2^{\circ}$ ) metre-thick master beds. At the bed scale, the climbing angle progressively increases upwards: subcritical at the base, then supercritical up to in-phase aggradation of a sinusoidal lamination. In some cases, ripple morphologies were subsequently draped by mud layers (Figure S7B). Syn-sedimentary extensional fractures have disrupted the bedding (Figure S7). The uppermost $5 \mathrm{~m}$ of the succession is made up of erosion-based gravelly to pebbly cross-stratified sand (SGr2).

Interpretation. The facies suite is typical of (glacio-) lacustrine deltas (e.g. Jopling \& Walker, 1968; Nutz et al., 2015); they are organized as well-laminated fine-grained bottomsets, climbing ripples in foresets and gravelly topsets. Suspension-charged river outflows arriving into the lake directly plunged owing to density contrasts between the flow and the ambient water body. They formed climbing-ripple assemblages that essentially recorded waning stage flow conditions as shown by the increasing angle of climb (Jobe et al., 2012). The stratal pattern likely reflects seasonal meltwater discharge with mud drapes possibly representing low-inputs during winter conditions.

\section{DEVELOPMENT OF THE PORTNEUF- FORESTVILLE DELTAIC COMPLEX}

A four-stage development (Fig. 8; Table 3), which echoes the depositional systems detailed above (depositional system I in the cliff, in-valley depositional system and depositional systems II and III), is proposed on the basis of landform assemblages (Fig. 1 and Figure S1), stratigraphic architectures (Figs 2 and 4), depositional facies (Figs 5 to 7) and radiocarbon dating (Table 1). Each stage is characterized by specific forcing parameters and sedimentation patterns (depositional rates, shoreline trajectories and relative intensity of marine reworking processes, Table 3).

\section{Temporal framework}

Combined with stratigraphic relationships, the internal coherency of the set of 12 radiocarbon dates (Table 1) allows for a robust temporal framework to be established. Although no radiocarbon date is directly available from the sandy upper delta slope deposits, ages are easily approximated by physical correlation with the lower delta slope (Fig. 2). From the age available in the glaciomarine mud (sample 30-2, 11 $170 \pm 70$ year cal BP) to the older age available in the muddy lower delta slope (sample 2-2-a, $10600 \pm 115$ year cal BP), a time span of $c a$ 600 years accounts for the deposition of the outwash fan, the fjord head (Portneuf) and the moraine-dammed lacustrine (Sault-au-Cochon) deltas, and a notable part of the open-coast deltaic progradation (Fig. 2). This 600 year time span corresponds primarily to the period of invalley and open-coast deltaic progradation that began with the development of the outwash fan; the latter most probably lasting a few hundreds of years in comparison with similar depositional settings (e.g. Nemec et al., 1999; Lønne et al., 2001; Occhietti, 2007). A RSL curve is proposed here (Fig. 9) that represents the best fit between available radiocarbon dates and both observed and inferred stratigraphic relationships.

\section{Ice-contact outwash fan (12.2 to $11 \mathrm{kyr}$ cal BP; shorelines from $>140 \mathrm{~m}$ to 125 m.a.s.l.)}

After the disintegration of the LIS across the St. Lawrence Gulf and Estuary, the marine-based ice margin stabilized along the Canadian Shield and marine invasion extended over glacio-isostatically flexed lowlands (Goldthwait Sea). At that time, a fundamental dichotomy is noted between the successions observed at the outlets of the Sault-au-Cochon and Portneuf valleys. At the Sault-au-Cochon Valley outlet and beyond, down to the cliff (Fig. 4), an extensive ice-contact wedge was formed (depositional system I). 


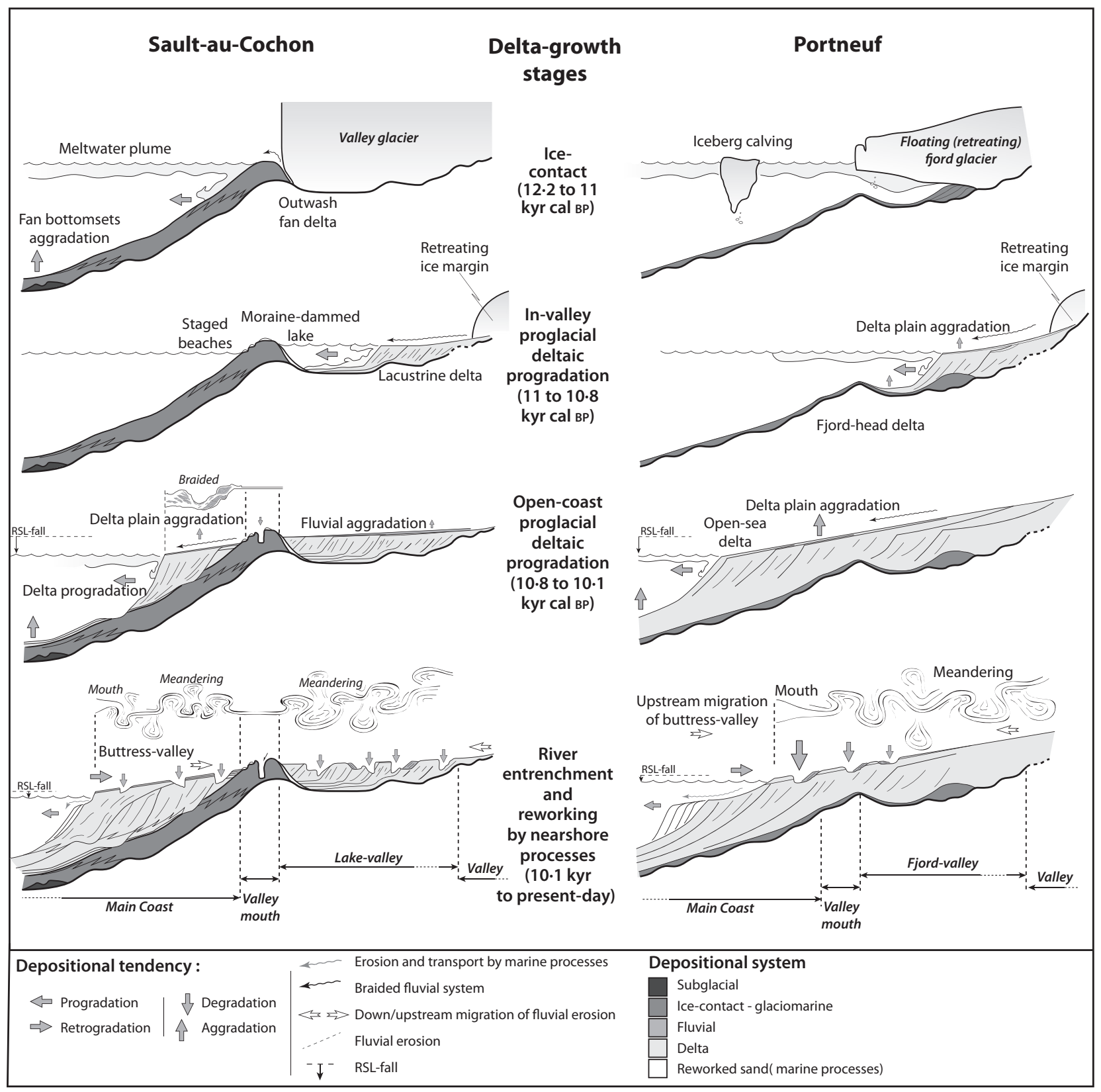

Fig. 8. The four stages of development of the Portneuf-Forestville deltaic complex, differentiating the distinctive stratigraphic evolution tied to the Portneuf (right) and Sault-au-Cochon (left) counterparts.

Here, the ice margin stabilized and an ice-contact depositional wedge developed at the stillstand position (Fig. 8). The ice-contact wedge initially developed downslope into a muddy glacimarine turbiditic outwash system expanding down to the location of the present-day cliff (DU2; Figs 2 and 3). The upward disappearance of IRD and the onset of sand deposition characterize the transition from glacimarine muds to the distal outwash fan, those two elements being the signature of a subaqueous to terrestrial ice-front transition. The emergence of the fan resulted from a combination of sedimentary aggradation and RSL fall (e.g. Lønne et al., 2001). At least one another outwash fan with a top surface lying at 140 m.a.s.l. is present at the outlet of the Cedars Lake valley (Figure S1). In contrast, at the Portneuf Valley outlet, the absence of any icecontact deposits and the limited amount of glacimarine muds during deglaciation implies that the ice front retreated significantly further up valley. At that time, the future Portneuf Peninsula was a 
Table 3. Summary and semi-quantitative analysis of the characteristics of the four successive stages constituting the forced regressive deglacial sequence documented in the Portneuf Peninsula since $12.5 \mathrm{kyr}$ cal BP.

\begin{tabular}{|c|c|c|c|c|}
\hline $\begin{array}{l}\text { Depositional } \\
\text { system }\end{array}$ & Ice-contact & $\begin{array}{l}\text { In-valley deltaic } \\
\text { progradation }\end{array}$ & $\begin{array}{l}\text { Open-coast deltaic } \\
\text { progradation }\end{array}$ & $\begin{array}{l}\text { Coastal sedimentary } \\
\text { suites }\end{array}$ \\
\hline $\begin{array}{l}\text { Sedimentary } \\
\text { structures }\end{array}$ & Deglacial & $\begin{array}{l}\text { Proglacial } \\
\text { (Ice-marginal retreat) }\end{array}$ & $\begin{array}{l}\text { Proglacial (ablating } \\
\text { ice margin) }\end{array}$ & $\begin{array}{l}\text { Paraglacial (Ice margin } \\
\text { retreated out from the } \\
\text { drainage basins) }\end{array}$ \\
\hline $\begin{array}{l}\text { Depositional } \\
\text { units }\end{array}$ & $\begin{array}{l}\text { Outwash fan DU3 } \\
\text { Glaciomarine mud } \\
\text { DU2 Esker DU1 }\end{array}$ & $\begin{array}{l}\text { Fjord head and } \\
\text { lacustrine deltas }\end{array}$ & $\begin{array}{l}\text { Delta plain DU6 } \\
\text { Upper delta slope } \\
\text { DU5 Lower delta } \\
\text { slope DU4 }\end{array}$ & $\begin{array}{l}\text { Nearshore sand sheet } \\
\text { DU8 Spit platform } \\
\text { DU7 }\end{array}$ \\
\hline $\begin{array}{l}\text { Timing } \\
\text { (duration) }\end{array}$ & $\begin{array}{l}12.5 \text { to } \sim 11 \mathrm{kyr} \text { cal } \\
\mathrm{BP}(\sim 1.5 \mathrm{kyr})\end{array}$ & $\begin{array}{l}\sim 11 \text { to } 10.8(?) \mathrm{kyr} \\
\text { cal BP }(\sim 0.2 \mathrm{kyr})\end{array}$ & $\begin{array}{l}10.8(?) \text { to } 10.1 \mathrm{kyr} \mathrm{cal} \\
\mathrm{BP}(\sim 0.7 \mathrm{kyr})\end{array}$ & $\begin{array}{l}10.1 \mathrm{kyr} c a l \mathrm{BP} \text { to } \\
\text { today }(>10 \mathrm{kyr})\end{array}$ \\
\hline $\begin{array}{l}\text { RSL fall } \\
\text { Sedimentary } \\
\text { volume }\end{array}$ & $\begin{array}{l}140 \text { to } 125 \mathrm{~m} \\
2 \pm 0.5 \mathrm{~km}^{3} \\
\text { (Sault-au-Cochon } \\
\text { River outlet) }\end{array}$ & $\begin{array}{l}125 \text { to } 110 \mathrm{~m} \\
\text { Fjord (Portneuf): } \\
<3 \mathrm{~km}^{3} \text { Lake } \\
\text { (Sault-au-Cochon): } \\
1.5 \pm 0.5 \mathrm{~km}^{3}\end{array}$ & $\begin{array}{l}110 \text { to } 90 \mathrm{~m} \\
\sim 5 \mathrm{~km}^{3}\end{array}$ & $\begin{array}{l}90 \text { to } 0 \mathrm{~m} \\
\text { Unsignificant } \\
\text { (sediment reworking) }\end{array}$ \\
\hline $\begin{array}{l}\text { Progradation } \\
\text { length }\end{array}$ & 4 to $10 \mathrm{~km}$ & $\sim 60 \mathrm{~km}$ & $10 \mathrm{~km}$ & $\begin{array}{l}\text { To the south: To the } \\
\text { north: } 5 \mathrm{~km} \text { to } 5 \mathrm{~km} \\
\text { (retrogradation) }\end{array}$ \\
\hline $\begin{array}{l}\text { Progradation } \\
\text { rate }\end{array}$ & $\varnothing$ & $\sim 200 \mathrm{~m} \cdot$ year $^{-1}$ & $\sim 15 \mathrm{~m} \cdot$ year $^{-1}$ & $\begin{array}{l}\sim 0.5 \mathrm{~m} \cdot \mathrm{year}^{-1} \text { to } \\
\sim-0.5 \mathrm{~m} \cdot \mathrm{year}^{-1}\end{array}$ \\
\hline $\begin{array}{l}\text { Shoreline } \\
\text { trajectory }\end{array}$ & $\varnothing$ & $\begin{array}{l}\text { Accretionary } \\
\text { Descending Regressive } \\
\text { (Portneuf valley: } \\
0.08 \%=0.04^{\circ} \text { ) }\end{array}$ & $\begin{array}{l}\text { Accretionary } \\
\text { Descending } \\
\text { Regressive } \\
\left(0.2 \%=0.115^{\circ}\right)\end{array}$ & $\begin{array}{l}\text { Accretionary } \\
\text { Descending } \\
\text { Regressive } \\
\left(1.5 \%=0.86^{\circ}\right)\end{array}$ \\
\hline
\end{tabular}

glacimarine bay at the outlet of a fjord, with adjacent outwash fans.

The Sault-au-Cochon ice-contact outwash fan, which has a radius in excess of $15 \mathrm{~km}$, stored gravelly to sandy sediments from the presentday $140 \mathrm{~m}$ elevation (marine limit) down to beyond the current sea-level. Associated glacimarine muds expand largely further to the east into the St. Lawrence Estuary where they correlate with depositional units 2 and 3 of the regional seismostratigraphy (Syvitski \& Praeg, 1989; unit S2 in Duchesne et al., 2010). In the Portneuf Peninsula, the volume estimate of outwash sediments accounting for known thicknesses and their lateral extent is $2 \pm 0.5 \mathrm{~km}^{3}$ (Table 3).

\section{In-valley proglacial deltaic progradation (11 to $10 \cdot 8 \mathrm{kyr}$ cal. BP; shorelines from $125 \mathrm{~m}$ to 110 m.a.s.l.)}

The second stage followed the retreat of the ice margin from its former stillstand at the outlet of the Sault-au-Cochon valley. Because no other nearby ice-marginal wedge has been identified up valley, the retreat of the ablating ice margin in the Sault-au-Cochon Valley area was probably rapid (Fig. 8). The initial dichotomy between the Portneuf and Sault-au-Cochon valleys persisted as distinctive sedimentation styles characterize the infills of the two valleys: a morainedammed lacustrine delta in the Sault-au-Cochon Valley, a fjord head delta in the Portneuf Valley (in-valley depositional system). Beach ridges descending from 140 to $120 \mathrm{~m}$ along the basinfacing side of the abandoned and progressively emerging outwash fan shows that the marine shore was then temporarily sediment starved, owing to sediment retention in the morainedammed lacustrine delta. The stage of in-valley deltaic progradation is a very short period of time ( $c a 200$ year) relative to the overall outwash to deltaic development (>2000 year; Table 3). The estimated volume of the sedimentary wedges is $<3.0 \mathrm{~km}^{3}$ and $1.5 \mathrm{~km}^{3}$, for the Portneuf and Sault-au-Cochon valleys, respectively (Table 3 ). The short time interval corresponding to this in-valley deltaic progradation implies very high progradation rates $\left(>200 \mathrm{~m} \cdot \mathrm{year}^{-1}\right)$, which are three to four times higher than those recorded in present-day fjord 


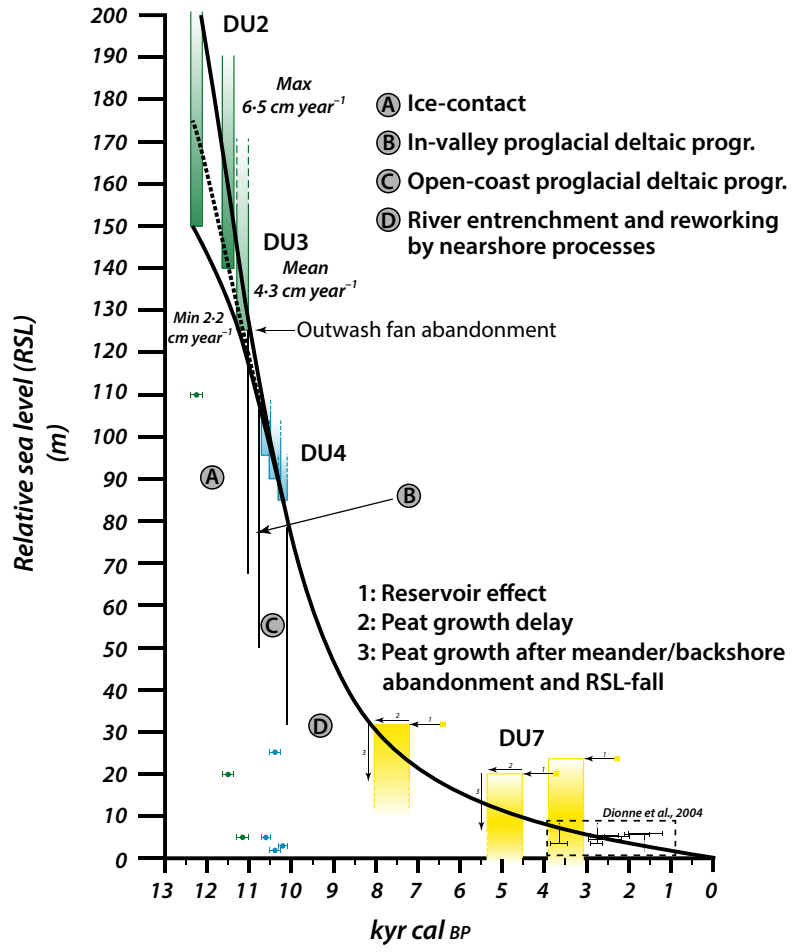

Fig. 9. Reconstructed relative sea-level curve for the Portneuf Peninsula. The last two thousand years are partly derived from data published in Dionne et al. (2004). Colours relate to the depositional systems depicted in Fig. 2. Dots with error bars represent sampled and dated shell debris and organic matter (Table 1), and rectangles having a colour gradient reflect depositional units.

head settings (e.g. Cowan et al., 1998, 50 to $70 \mathrm{~m} \cdot$ year $^{-1}$; Gilbert \& Crookshanks, 2009, $50 \mathrm{~m} \cdot$ year $^{-1}$ ). High progradation rates resulted from the combined effects of effective RSL fall, high sediment discharge from the actively ablating LIS margin and reduced accommodation space owing to deposition in narrow bedrockconfined valleys (e.g. Eilertsen et al., 2011). The shoreline trajectory of the fjord head delta was descending accretionary regressive, sensu Helland-Hansen \& Hampson (2009). Although the downdip angle is poorly constrained, a maximal value can be assessed from the minimal gradient of the highest preserved fluvial terraces ( $\mathrm{ca}$ $0.08 \%$, Table 3), keeping in mind the differential glacio-isostatic flexure (Shaw et al., 2002).

\section{Open-coast proglacial deltaic progradation (10.8 to 10.1 kyr cal BP; shorelines from $110 \mathrm{~m}$ to 90 m.a.s.l.)}

The third stage is characterized by the development of a large and voluminous fluviodeltaic body (Depositional system II) after coalescence of the two deltaic systems now exiting the valley outlets (in-valley depositional system) at $c a$ 110 m.a.s.l. and freely developing into an open-coast setting (Fig. 8). Regarding the Portneuf Valley, the open-coast deltaic progradation is the direct continuation of the fjord head delta. In contrast, a rejuvenation of the Sault-au-Cochon delta occurred after the infill of the moraine-dammed lake was completed; the antecedent lake outlet probably focusing the river mouth down to the regressive shorelines. Lower delta slope deposits (DU4) downlap the distal part of the outwash (DU3, Figs 2 and 4) and we then infer that topset beds of the rejuvenated Sault-au-Cochon delta onlapped against the depositional slope of the former proximal outwash fan (Figure S2A). The stratigraphic hiatus between DU3 and DU4, expressed by the virtual cessation of sand deposition (Fig. 2), corresponds to the time of lake infilling by the moraine-dammed lacustrine delta (Fig. 8). The channel structures found in the lower and upper delta slope (DU4 and DU5) were the feeder of basin floor fans located in the Laurentian Trough (Unit 4 in Syvitski \& Praeg, 1989).

The open-coast progradation produced a $c a$ $5 \mathrm{~km}^{3}$ volume of sediment, considering an area of $100 \mathrm{~km}^{2}$ (Figure S1) and a mean thickness of $c a 50 \mathrm{~m}$ (Fig. 2). The progradation rate was about $15 \mathrm{~m} \cdot$ year $^{-1}$, showing an order of magnitude deceleration relative to the in-valley sedimentation (Table 3). This progradation rate reflects the significant increase in accommodation space provided by the depositional basin rather than a decrease in sediment supply (Fig. 10).

Interestingly, neither delta plain accretion nor fluvial entrenchment was noted during this stage, in spite of the forced regressive setting (Fig. 9). Further, the in-valley and open-coast deltaic accretions are characterized by similar facies, suggesting that sustained meltwater flows issuing from the ablating ice sheet maintained significant water and sediment discharge in the river catchment.

\section{River incision and reworking by nearshore processes (from 10.1 kyr cal BP to present- day; shorelines from $90 \mathrm{~m}$ to 0 m.a.s.l.)}

The geomorphic and sedimentary records together indicate a major change when the RSL reached 90 m.a.s.l. (Fig. 2; Figure S1). The 

plain accretion during RSL fall, as understood from the relationship between the fluvial gradient $(\alpha)$ and the shoreline trajectory angle $(\beta)$. (A) During the early proglacial deltaic progradation. (B) Fluvial entrenchment during the later paraglacial evolution. (C) Presentday situation illustrating the influence of local base levels imposed by bedrock sills (see text for details).
Fig. 10. Conceptual model for delta

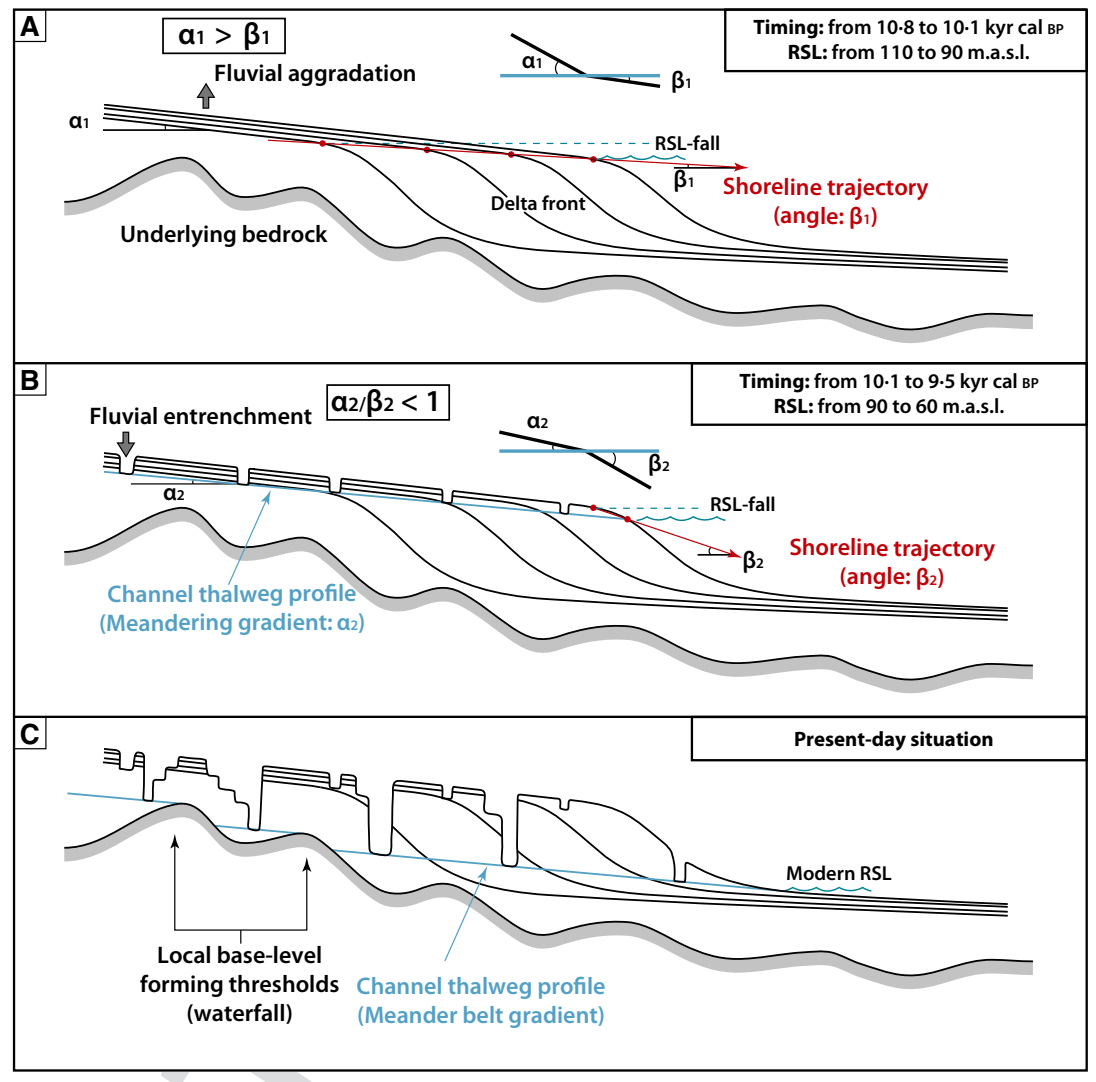

presence of beach ridges and associated deposits (Depositional system III) below $90 \mathrm{~m}$ elevation demonstrates the increased importance of marine processes relative to fluvial ones. The transition is interpreted as the result of a dramatic decrease in the fluvial input rather than being tied to an increase in wave energy (e.g. Swenson et al., 2005). The present authors inferred that active coastal erosion began at that time in the northern Peninsula, nourishing spit progradations to the south. The braided fluvial network was no longer active and meandering rivers started to incise into the underlying deltaic sediment pile, contributing also to sediment reworking and spit accretion. The transitional boundary between the last deposits of DU4 and DU5 (Fig. 2, km 2.5 to 3.3 ), in contrast to scouring processes that occurred primitively further to the north, reflects the progressive decline in fluvial input that preceded the onset of predominance of coastal processes.

Relative sea-level was continuously falling during this phase. The shoreline trajectory, best represented by the surf diastem geometry (lower bounding surface of the nearshore sand sheet, Figs 2 and 7H) showed a biphased evolution. Initially, shorelines migrated over the inherited upper delta slope deposits (from $\mathrm{km} 7 \cdot 0$ to $2 \cdot 6$,
Fig. 2), and a severe truncation with shoreface deposits was observed here. The limited accommodation space resulted in a descending, nonaccretionary regressive shoreline trajectory (Helland-Hansen \& Hampson, 2009). From the point at which the shoreline crossed the inherited,

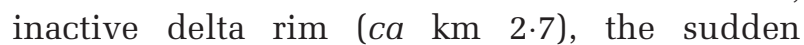
depth increase led to the construction of a spit platform. As a consequence, the descending regressive shoreline trajectory became distinctively accretionary (Figs 2 and 10). Meanwhile, fluvial meanders formed on the delta plain and were successively abandoned and stepped from 65 to 15 m.a.s.l., below the rising, abandoned delta surface currently lying at elevations between $110 \mathrm{~m}$ and $90 \mathrm{~m}$ (Fig. 1; Figure S1). In places, total fluvial erosion depths are in excess of $50 \mathrm{~m}$, denoting a fluvial entrenchment (Fig. 4).

\section{DISCUSSION}

\section{Anatomy of the forced regressive deglacial sequence}

This study demonstrates that the deltaic complex is temporally tied to a forced regressive 
evolution. Volumetrically, most of the deposits that constitute the deltaic complex relate to the ice-contact, in-valley and open-coast progradation stages (Table 3). In other words, the forced regressive deltaic complex represents the deglaciation record. It displays the following characteristics:

1 Coarse-grained ice-contact sediment bodies (the esker and the proximal outwash fan) are volumetrically minor relative to the fine-grained, ice-distal sediment bodies (glaciomarine muds and distal outwash fan), which generally onlap directly the basal glacial erosion surface.

2 Two successive coarsening-upward depositional systems (excluding the esker) together built a >50 to $100 \mathrm{~m}$ thick sediment wedge in a restricted time interval. The lower system resulted from outwash fan progradation (DU3), the upper system corresponding to delta progradation (DU4 to DU6). In the cliff, they are superimposed but they may be laterally juxtaposed in other case studies.

3 The deltaic progradation of the deglacial sequence was emplaced in a forced regressive setting and then does not correspond to a postglacial system characterizing highstand conditions. In domains with a lesser isostatic rebound, similar sediment bodies are referred to as 'lowstand delta' (Hein et al., 2014).

4 Delta plain accretion was maintained during initial, rapid RSL fall but fluvial incision occurred counter-intuitively later, when the rate of RSL fall had already decreased significantly (Fig. 9).

5 Progradations (outwash and delta) left behind a thick $(>100 \mathrm{~m})$ depositional wedge representing a relatively short time interval ( $c a$ 2000 year; Figs 8 and 9). Such a succession would have been easily misinterpreted as a typical thirdorder depositional sequence in the absence of any high-resolution time constrains and/or any detailed stratigraphic architecture.

6 The late depositional evolution was dominated by shallow marine reworking (DU7 and DU8) of the outwash and delta sediment wedges, with no substantial fluvial input. In other words, the deltaic complex is essentially inactive today (see also Normandeau et al., 2015).

This type of deglacial sequence differs from other successions where glaciomarine depositional systems are predominant in terms of sediment volumes and related accumulation rates (e.g. Boulton, 1990; Syvitski \& Lee, 1997; Powell
\& Cooper, 2002). Here, the ice-contact depositional system (outwash fan and glacimarine muds) contributed to only about $20 \%$ of the overall volume of sediment deposited in the deltaic complex. The short depositional time interval denotes striking averaged accumulation rates in the 25 to $50 \mathrm{~m} \cdot \mathrm{kyr}^{-1}$ range, which is a conservative estimate. Nevertheless, depositional suites are made up of regular facies associations and indeed no large mass flows or megabeds have been recognized. It thus implies high preservation rates of the successive event beds and minor intervening erosional or a non-depositional hiatus throughout the succession. Without a framework based on radiocarbon dating, these relationships would have remained unsuspected. Such deglacial sequences may have been underestimated when deciphering the deep time (de)glacial record. The short duration of deposition, negating the role of subsidence in the depositional stratigraphic architecture of such forced regressive deglacial sequences, would be viewed as virtually instantaneous in the coarser resolution deep time record (Girard et al., 2015). In the forced regressive context, accommodation space is then only provided by inherited topographies.

\section{Control of drainage basin extent on sedimentary architecture}

The turnaround terminating the actively prograding open-coast phase occurred when the RSL reached the break-in-slope at the $90 \mathrm{~m}$ elevation (Fig. 8). This transition has clear signatures in terms of stratigraphic architecture and depositional facies as shown by: (i) the onset of the river entrenchment after a period of delta plain accretion; (ii) the replacement of the braided plains by entrenched, meandering streams; (iii) the generalization of coastal forms (spit, berms and back barrier marshes); and (iv) the demise of turbiditic deposition over the delta slope, concurrent with the onset of the spit platform to the south and coastal erosion to the north. These elements suggest that the system evolved from a high-discharge fluvial-dominated depositional system to a new state, within which shallow marine depositional processes largely prevail over river dynamics.

In glaciation settings, the abrupt decrease in sediment supply is recurrently associated with the retreat of ice sheet margins from river drainage basins (Church, 1972; Syvitski, 1989; Syvitski \& Hein, 1991; Forbes \& Syvitski, 1994; 
Corner, 2006; Eilertsen et al., 2011; Nutz et al., 2014), considering that glacier-related sediment yields are greater by one or two order of magnitude relative to those in non-glaciated basins (Church \& Slaymaker, 1989; Syvitski \& Lee, 1997). The sediment starvation hypothesis is in good agreement with: (i) the transition from delta plain accretion to river entrenchment in such a context of RSL fall (e.g. Leeder \& Stewart, 1996; Blum \& Törnqvist, 2000; Klinger et al., 2003); and (ii) the enhanced marine processes on deltaic accretion patterns (Reading \& Collinson, 1996; Swenson et al., 2005). In the present case study, the age of the transition from proglacial, river-dominated deltaic progradation to the generalization of coastal processes confidently dates back to $10 \mathrm{kyr}$ cal BP owing to seven radiocarbon dates, in particular those recovered from lower delta slope muds (Fig. 2; Table 1). On the basis of ice sheet reconstructions (Occhietti et al., 2011) and considering the extent to the north-west of the drainage areas of the Portneuf and Sault-au-Cochon rivers, this age precisely coincides with a LIS margin positioned close to the uppermost watershed of the two rivers (Fig. 1B). Thus, this transition is interpreted here as the signature of the retreat of the LIS margin out of the Portneuf and Sault-au-Cochon drainage areas. It corresponds for the deltaic complex to a proglacial-to-paraglacial transition. The shutdown of the glaciogenic sediment supply transformed an actively prograding delta into a depositional system essentially dominated by shallow marine reworking processes (see also

30 Forbes \& Syvitski, 1994; Swenson et al., 2005). The reduction in river-derived sediment supply caused either coastal erosion or progradation of beach/barrier systems, depending on patterns of longshore drift (Bernatchez \& Dubois, 2004; Korus \& Fielding, 2015). It follows that one of the main stratigraphic discontinuity and erosion surfaces within the forced regressive deglacial sequence derived from the relatively far-field deglaciation development in the drainage basins rather than to local changes, for instance the interplay between RSL fall and inherited topographies.

\section{Fluviodeltaic deposition during relative sea- level fall: from accretion to river entrenchment}

The well-preserved Portneuf-Forestville forced regressive deglacial sequence offers a unique opportunity to test recent models and concepts dealing with possible sediment deposition during RSL fall. Subsurface (McMurray \& Gawthorpe, 2000; Tesson et al., 2000; Rabineau et al., 2005) and outcrop (e.g. Bhattacharya \& Willis, 2001; Porębski \& Steel, 2006; Fielding, 2015) case studies have usually indicated that limited or no fluvial/delta plain deposits are typically associated with falling stage system tracts (FSST); however, it is rarely determined whether such deposits are lacking because of bypass or erosion during forced regression or owing to subsequent transgressive ravinement surfaces (Plint \& Nummedal, 2000; Posamentier \& Morris, 2000; Catuneanu, 2002; Embry, 2010; Santra et al., 2013). Significant volumes of fluvial sediments can be nevertheless deposited and preserved within the FSST. In particular, subaerial deposition during RSL fall has been long recognized to occur where the downstream basin topography has a gradient lower than that of the fluvial equilibrium profile (Schumm, 1993; Burgess \& Allen, 1996; Browne \& Naish, 2003; Zecchin, 2007; Holbrook \& Bhattacharya, 2012; Blum et al., 2013). Fluvial aggradation during forced regression can also be understood as the result of a high rate of sediment supply associated with low diffusion rates in subaerial environments; a situation implying that sediment supply exceeds the carrying capacity of the rivers (Swenson \& Muto, 2007; Prince \& Burgess, 2013; Fontana et al., 2014).

This study has described a deltaic complex that was entirely emplaced in a context of sustained RSL fall (Fig. 9). Its evolution was twofold: (i) early proglacial dynamics (shorelines above 90 m.a.s.l.), showing fluviodeltaic accretion and no river incision, but coeval with high rate of sea-level fall ( 3 to $5 \mathrm{~cm} \cdot$ year $^{-1}$ ) and a high sediment supply; (ii) late paraglacial dynamics (shorelines below 90 m.a.s.l.), characterized by river entrenchment, lower rates of RSL fall $\left(<3 \mathrm{~cm} \cdot\right.$ year $\left.^{-1}\right)$ and restricted sediment supply. In both cases, the basin slope was greater than the fluvial gradient. Fluvial aggradation was possible, however, owing to high rates of sediment supply and 'neutralization' (sensu Leeder \& Stewart, 1996) of the progressive water depth increase during progradation of the delta. The case study here is an illustration of some model predictions that consider the massive reduction in sediment supply as being potentially responsible for river incision (Muto \& Swenson, 2006; Swenson \& Muto, 2007).

The signature of the proglacial-to-paraglacial transition can also be illustrated in terms of 
shoreline trajectory (Helland-Hansen \& Hampson, 2009). In the proglacial setting, the fluvial gradient $\left(\alpha_{1}\right)$ is best expressed by the delta plain slope gradient between $110 \mathrm{~m}$ and 90 m.a.s.l. ( $\mathrm{ca} 0.25 \%$ ), considering that it represents a snapshot of the braided fluvial system immediately prior to its abandonment (Fig. 10; Figure S1). Such a relatively high gradient is, however, consistent with that of a present-day sandar $(0.14$ to $3.0 \%$, Maizels, 2002). An estimate of the shoreline trajectory angle $\left(\beta_{1}\right)$ during the open-coast progradation is $\mathrm{Ca} 0.2 \%$ (see above; Figs 2 and 4, Table 3). Hence, when the RSL fell from 110 to 90 m.a.s.l., the ratio $\alpha_{1} / \beta_{1}$ was slightly more than 1 , allowing a limited but definite topset aggradation (Fig. 10; see also Helland-Hansen \& Hampson, 2009; their fig. 9G). The paraglacial fluvial entrenchment and related downstepping meanders (Fig. 4; Figure S1) conform to a more conventional forced regressive evolution. Here, the shoreline trajectory in the axis of the meandering river essentially reflected interactions between the RSL fall rates and the inherited basin slope (Helland-Hansen \& Hampson, 2009). The gradient of the paraglacial meandering river $\left(\alpha_{2}\right)$, either estimated from DEM or inferred from present-day coastal meanders flowing into the St. Lawrence Estuary and Gulf, was significantly flatter ( $c a 0.05$ to $0 \cdot 8 \%$ ) than that of the earlier braided streams. Below 90 m.a.s.l. and beyond the former delta brink, the new shoreline trajectory angle $\left(\beta_{2}\right)$ was scaled approximatively to the angle of the inherited deltaic depositional profile, which was relatively steep ( $>1 \%$, Figs 2,4 and 10$)$. Thus, the paraglacial $\alpha_{2} / \beta_{2}$ ratio was $\ll 1$, a condition leading straightforwardly to river incision in conditions of restricted sediment supply. Following the shutdown of the glaciogenic sediment supply, river entrenchment was initiated upvalley, from the head of the drainage basins, with subsequent downstream migration (buffer valley model of Holbrook \& Bhattacharya, 2012). Concomitantly, processes of fluvial incision leading to stepped and abandoned coastal meanders adjusted to the shoreline originated from an upstream migrating incision. It corresponds to the buttress valley model of Holbrook \& Bhattacharya (2012) (Fig. 8).

\section{CONCLUSIONS}

In this study, a post-Late Glacial Maximum (LGM) forced regressive, deglacial sequence was documented mainly on the basis of landforms, stratigraphic architectures and radiocarbon dating. Facies associations were described in order to highlight depositional processes along the deltaic profile, but related palaeobathymetries were primarily inferred from the overall deltaic architecture. This case study provides an outcrop analogue for currently submerged lowstand deltas in the eastern Canadian outer shelf for example, only illustrated by seismic dataset or shallow cores. It is envisioned here that forced regressive deltaic complexes, related stratigraphic architecture and associated depositional facies definitely have preservation potential if (i) relatively thick depositional proglacial wedges have been emplaced and (ii) they are located in areas experiencing a significant relative sea-level (RSL) rise after deglaciation where a post-glacial glacio-eustatic transgression succeeds to an initial glacio-isostatic rebound. This study demonstrates that the bulk of the sediment volume, originating from ice-contact and forced regressive delta dynamics, relates to very short-lived $(<2000$ year here $)$ stages of the glacial retreat and associated sedimentation. Most of the paraglacial time is essentially associated with sediment reworking and redistribution, either in regressive or transgressive conditions. This study is significant for the understanding of both Quaternary and pre-Quaternary forced regressive, deglacial successions because it highlights a case of stratigraphic distortion primarily linked to glacially controlled patterns of sediment supply rather than to accommodation trends. Indeed, timescales in proglacial-to-paraglacial sediment deposition are one to three orders shorter than basinal subsidence patterns. Being disconnected from the global sea-level cycle, careful examination is required in the identification of glacio-isotatically forced regressive deltaic complexes that record a deglaciation. Based on the Portneuf-Forestville case study, their main features should be as follows:

1 Underlying glacially related sediments wedges, from thin till covers to thick, but spatially restricted, ice-contact outwash fan deposits.

2 A shallowing-upward tripartite succession from a mud-dominated lower delta slope, sandprone turbiditic upper delta slope to proglacial braided delta plain deposits.

3 A shift from active deltaic accretion to a shallow marine reworking stage, which marks the retreat of the ice sheet margin from the drainage basin of the rivers. 
4 Raised and stepped beach structures, staged from the marine limit down to the interglacial shoreline, which will probably be reworked during any ensuing transgression.

5 Fluvial entrenchment processes occurring late in the deglacial history and marking the onset of the paraglacial evolution in the delta plain.

A diagnostic criteria differentiating glacio-isostatically forced regressive deltas from other glaciation-related deltaic successions are the embedded record of a drastic reduction in sediment supply. It is in contrast with other forced regressive systems where sediment supply is increasing during the forced regression.

\section{ACKNOWLEDGEMENTS}

The authors are grateful to Associate Editor Chris Fielding and two anonymous reviewers, as well as Massimiliano Ghinassi and Daniel Le Heron for their constructive and helpful comments that greatly contributed to the improvement of the manuscript. Field campaigns and datings were funded by action SYSTER and the ARTEMIS program (LMC14) of INSU-CNRS. Xray analyses were kindly provided by Dr. JeanMichel Friedmann. We also thank Dany Zbinden (Mériscope) for the boat trip along the sea cliff. This work is a contribution to the 'SeqStrat-Ice' ANR project 12-BS06-14.

\section{REFERENCES}

Anthony, E.J. (2008) Shore Processes and Their Palaeoenvironmental Applications. Elsevier, Amsterdam.

Ayranci, K., Lintern, D.G., Hill, P.R. and Dashtgard, S.E. (2012) Tide-supported gravity flows on the upper delta front, Fraser River delta, Canada. Mar. Geol., 326-328, 166-170.

Babonneau, N., Savoye, B., Cremer, M. and Bez, M. (2010) Sedimentary Architecture in Meanders of a Submarine Channel: detailed Study of the Present Congo Turbidite Channel (Zaiango Project). J. Sediment. Res., 80, 852-866.

Bard, E., Arnold, M., Mangerud, J., Paterne, M., Labeyrie, L., Duprat, J., Mélières, M.-A., Sønstegaard, E. and Duplessy, J.-C. (1994) The North Atlantic atmosphere-sea surface $14 \mathrm{C}$ gradient during the Younger Dryas climatic event. Earth Planet. Sci. Lett., 126, 275-287.

Batchelor, C.L. and Dowdeswell, J.A. (2015) Ice-sheet grounding-zone wedges (GZWs) on high-latitude continental margins. Mar. Geol., 363, 65-92.

Bernatchez, P. (2003) Evolution littorale Holocène et actuelle des complexes deltaïques de Betsiamites et de Manicouagan - Outardes: synthèse, processus, causes et perspectives. Université Laval, Québec.

Bhattacharya, J.P. and Willis, B.J. (2001) Lowstand deltas in the Frontier Formation, Powder River basin, Wyoming: implications for sequence stratigraphic models. AAPG Bull., 85, 261-294.

Blum, M.D. and Törnqvist, T.E. (2000) Fluvial response to climate and sea-level change: a review and look forward. Sedimentology, 47, 2-48.

Blum, M., Martin, J., Milliken, K. and Garvin, M. (2013) Paleovalley systems: insights from Quaternary analogs and experiments. Earth Sci. Rev., 116, 128-169.

Boulton, G.S. (1990) Sedimentary and sea level changes during glacial cycles and their control on glacimarine facies architecture. In: Glacimarine Environments: Processes and Sediments (Eds J.A. Dowdeswell and J.D. Scourse), 53, pp. 15-52. Geological Society Special Publication, London.

Bourgault, D., Morsilli, M., Richards, C., Neumeier, U. and Kelley, D.E. (2014) Sediment resuspension and nepheloid layers induced by long internal solitary waves shoaling orthogonally on uniform slopes. Cont. Shelf Res., 72, 2133.

Boyer-Villemaire, U., St-Onge, G., Bernatchez, P., Lajeunesse, P. and Labrie, J. (2013) High-resolution multiproxy records of sedimentological changes induced by dams in the Sept-Îles area (Gulf of St. Lawrence, Canada). Mar. Geol., 338, 17-29.

Breda, A., Mellere, D. and Massari, F. (2007) Facies and processes in a Gilbert-delta-filled incised valley (Pliocene of Ventimiglia, NW Italy). Sed. Geol., 200, 31-55.

Brookfield, M.E. and Martini, I.P. (1999) Facies architecture and sequence stratigraphy in glacially influenced basins: basic problems and water-level/glacier input-point controls (with an example from the Quaternary of Ontario, Canada). Sed. Geol., 123, 183-19.

Browne, G.H. and Naish, T.R. (2003) Facies development and sequence architecture of a late Quaternary fluvialmarine transition, Canterbury Plains and shelf, New Zealand: implications for forced regressive deposits. Sed. Geol., 158, 57-86.

Burgess, P.M. and Allen, P.A. (1996) A forward-modelling analysis of the controls on sequence stratigraphical geometries. Geol. Soc. Spec. Publ., 103, 9-24.

Carling, P.A. (2013) Freshwater megaflood sedimentation: what can we learn about generic processes? Earth Sci. Rev., 125, 87-113.

Cartigny, M.J.B., Postma, G., van den Berg, J.H. and Mastbergen, D.R. (2011) A comparative study of sediment waves and cyclic steps based on geometries, internal structures and numerical modeling. Mar. Geol., 280, 4056.

Catuneanu, O. (2002) Sequence stratigraphy of clastics systems: concepts, merits, and pitfalls. J. Afr. Earth Sc., 35, 1-43.

Choi, K. (2010) Rhythmic Climbing-Ripple Cross-Lamination in Inclined Heterolithic Stratification (IHS) of a Macrotidal Estuarine Channel, Gomso Bay, West Coast of Korea. J. Sediment. Res., 80, 550-561.

Church, M. (1972) Baffin Island sandurs: a study of Arctic fluvial processes. Geol. Surv. Can. Bull., 216, 208.

Church, M. and Slaymaker, O. (1989) Disequilibrium of Holocene sediment yield in glaciated British Columbia. Nature, 337, 452-454.

Clifton, H.E., Hunter, R.E. and Philipps, L. (1971) Depositional structures and processes in the non-barred high-energy nearshore. J. Sediment. Res., 41, 651-670.

Cousineau, P.A., Poirier, B., Brouard, E., El Amrani, M., Lajeunesse, P., Roy, D.W. and Walter, J. (2014) Rapport 
Final sur les travaux de cartographie des formations superficielles réalisés dans les territoires municipalisés de la Haute-Côte-Nord et de Charlevoix (Québec) entre 2012 et 2014. Ministère des ressources naturelles, Québec, 102 pp.

Cowan, E.A., Cai, J., Powell, R.D., Seramur, K.C. and Spurgeon, V.L. (1998) Modern tidal rhythmites deposited in a deep-water estuary. Geo-Mar. Lett., 18, 40-48.

Cummings, D.I., Gorrell, G., Guilbault, J.P., Hunter, J.A., Logan, C., Ponomarenko, D., Andre, J.M.P., Pullan, S.E., Russell, H.A.J. and Sharpe, D.R. (2011) Sequence stratigraphy of a glaciated basin fill, with a focus on esker sedimentation. Geol. Soc. Am. Bull., 123, 1478-1496.

Cutler, P.M., Colgan, P.M. and Mickelson, D.M. (2002) Sedimentologic evidence for outburst floods from the Laurentide Ice Sheet margin in Wisconsin, USA: implications for tunnel-channel formation. Quatern. Int., 90, 23-40.

Dietrich, P., Ghienne, J.-F., Normandeau, A. and Lajeunesse, P. (2016) Upslope-migrating bedforms in a proglacial sandur delta: cyclic steps from river-derived underflows? J. Sediment. Res., 86, 113-123.

Dionne, J.-C. (1996) La terrasse Mitis à la Pointe aux Alouettes, Côte Nord du Moyen Estuaire du Saint-Laurent, Québec. Géog. Phys. Quatern., 50, 57-72.

Dionne, J.-C. and Occhietti, S. (1996) Aperçu du Quaternaire à l'embouchure du Saguenay, Québec. Géog. Phys. Quatern., 50, 5-34.

Dionne, J.-C., Dubois, J.-M.M. and Bernatchez, P. (2004) La terrasse Mitis à la pointe de Mille-Vaches (péninsule de Portneuf), rive nord de l'estuaire maritime du SaintLaurent: nature des dépôts et évolution du niveau marin relatif à l'holocène. Géog. Phys. Quatern., 58, 281-295.

Dominguez, J.M.L. (1996) The São Francisco strandplain: A paradigme for wave-dominated deltas? In: Geology of Siliciclastic Shelf Seas (Eds M. De Batist and P. Jacobs), 117, pp. 21-231. Geological Society of London Special Publication, London.

Dredge, L.A. (1983) Surficial geology of the Sept-Iles area, Quebec North Shore. Geol. Surv. Can. Mem., 408, 40.

Duchesne, M.J., Pinet, N., Bolduc, A., Bédard, K. and Lavoie, D. (2007) Seismic Stratigraphy of the Lower StLawrence River Estuary (Quebec) Quaternary Deposits and Seismic Signature of the Underlying Geological Domains. Geological Survey of Canada, Current Research. D2, Xxxxxxxx.

Duchesne, M.J., Pinet, N., Bédard, K., St-Onge, G., Lajeunesse, P., Campbell, D.C. and Bolduc, A. (2010) Role of the bedrock topography in the Quaternary filling of a giant estuarine basin: the Lower St. Lawrence Estuary, Eastern Canada.. Basin Res., ????, ????-????

Dyke, A.S., Andrews, J.T., Clark, P.U., England, J.H., Miller, G.H., Shaw, J. and Veillette, J.J. (2002) The Laurentide and Innuitian ice sheets during the Last Glacial Maximum. Quatern. Sci. Rev., 21, 9-31.

Embry, A.F. (2010) Correlating siliciclastic successions with sequence stratigraphy. In: Application of Modern Stratigraphic Techniques: Theory and Case Histories (Ed.

35 X. Xxxxxxx), SEPM Spec. Publs, 35-53.

Erikson, L.H., Larson, M. and Hanson, H. (2007) Laboratory investigation of beach scarp and dune recession due to notching and subsequent failure. Mar. Geol., 245, 1-19.

Fielding, C.R. (2006) Upper flow regime sheets, lenses and scour fills: extending the range of architectural elements for fluvial sediment bodies. Sed. Geol., 190, 227-240.
Fielding, C.R. (2015) Anatomy of falling-stage deltas in the Turonian Ferron Sandstone of the western Henry Mountains Syncline, Utah: growth faults, slope failures and mass transport complexes. Sedimentology, 62, 1-26.

Fielding, C.R., Franck, T.D., Birgenheier, L.P., Rygel, M.C., Jones, A.T. and Roberts, J. (2008b) Stratigraphic record and facies associations of the late Paleozoic ice age in eastern Australia (New South Wales and Queensland). In: Resolving the Late Paleozoic Ice Age in Time and Space (Eds C.R. Fielding, T.D. Franck and J.L. Isbell), Geological Society of America Special Paper, 441, 41-57.

Fildani, A., Normark, W.R., Kostic, S. and Parker, G. (2006) Channel formation by flow stripping: large-scale scour features along the Monterey East Channel and their relation to sediment waves. Sedimentology, 53, 12651287.

Fontana, A., Mozzi, P. and Marchetti, M. (2014) Alluvial fans and megafans along the southern side of the Alps. Sed. Geol., 301, 150-171.

Forbes, D.L. and Syvitski, J.P. (1994) Paraglacial coasts. In: Coastal Evolution: Late Quaternary Shoreline Morphodynamics, pp. 373-424. (Eds R.W.G. Carter and C.D. Woodroffe), Cambridge University Press, Cambridge.

Fraser, C., Hill, P.R. and Allard, M. (2005) Morphology and facies architecture of a falling sea level strandplain, Umiujaq, Hudson Bay, Canada. Sedimentology, 52, 141160.

Gallaway, E., Trenhaile, A.S., Cioppa, M.T. and Hatfield, R.G. (2012) Magnetic mineral transport and sorting in the swash-zone: northern Lake Erie, Canada. Sedimentology, 59, 1718-1734.

Garcia, M. and Parker, G. (1989) Experiments on Hydraulic Jumps in Turbidity Currents Near a Canyon-Fan Transition. Science, 245, 393-396.

Ghienne, J.F. (2003) Late Ordovician sedimentary environments, glacial cycles, and post-glacial transgression in the Taoudeni Basin, West Africa. Palaeogeogr. Palaeoclimatol. Palaeoecol., 189, 117-145.

Ghienne, J.-F., Desrochers, A., Vandenbroucke, T.R.A., Achab, A., Asselin, E., Dabard, M.P., Farley, C., Loi, A., Paris, F., Wickson, S. and Veizer, J. (2014) A Cenozoicstyle scenario for the end-Ordovician glaciation. Nature Commun., 5, 1-9.

Gilbert, R. (1983) Sedimentary processes of canadian arctic fjord. Sed. Geol., 36, 147-175.

Girard, F., Ghienne, J.F. and Rubino, J.L. (2012) Occurrence of Hyperpycnal Flows and Hybrid Event Beds Related To Glacial Outburst Events In A Late Ordovician Proglacial Delta (Murzuq Basin, SW Libya). J. Sediment. Res., 82, 688-708.

Girard, F., Ghienne, J.-F., Du-Bernard, X. and Rubino, J.L. (2015) Sedimentary imprints of former ice-sheet margins: insights from an end-Ordovician archive (SW Libya). Earth Sci. Rev., 148, 259-289.

Gobo, K., Ghinassi, M. and Nemec, W. (2014) Reciprocal changes in foreset to bottomset facies in a Gilbert-type delta: response to short-term changes in base level. J. Sediment. Res., 84, 1079-1095.

Hansen, L. (2004) Deltaic infill of a deglaciated arctic fjord, East Greenland: sedimentary facies and sequence stratigraphy. J. Sediment. Res., 74, 422-437.

Hart, B.S. and Long, B.F. (1996) Forced regressions and lowstand deltas: Holocene Canadian examples. J. Sediment. Res., 66, 820-829. 
Helland-Hansen, W. and Hampson, G.J. (2009) Trajectory analysis: concepts and applications. Basin Res., 21, 454483.

Holbrook, J.M. and Bhattacharya, J.P. (2012) Reappraisal of the sequence boundary in time and space: Case and considerations for an SU (subaerial unconformity) that is not a sediment bypass surface, a time barrier, or an unconformity. Earth Sci. Rev., 113, 271-302.

Isbell, J.L., Cole, D.I. and Catuneanu, O. (2008) Carboniferous-Permian glaciation in the main Karoo Basin, South Africa: Stratigraphy, depositional controls, and glacial dynamics. Geol. Soc. Am. Spec. Pap., 441, 71-82.

Jakobsson, M., Anderson, J.B., Nitsche, F.O., Dowdeswell, J.A., Gyllencreutz, R., Kirchner, N., Mohammad, R., O'Regan, M., Alley, R.B. and Anandakrishnan, S. (2011) Geological record of ice shelf break-up and grounding line retreat, Pine Island Bay, West Antarctica. Geology, 39, 691-694.

Jobe, Z.R., Lowe, D.R. and Morris, W.R. (2012) Climbingripple successions in turbidite systems: depositional environments, sedimentation rates and accumulation times. Sedimentology, 59, 867-898.

Jopling, A.V. and Walker, R.G. (1968) Morphology and origin of ripple-drift cross-lamination, with examples from the Pleistocene of Massachussetts. J. Sediment. Petrol., 38, 971-984.

Josenhans, H. and Lehman, S. (1999) Late glacial stratigraphy and history of the Gulf of St. Lawrence, Canada. Can. J. Earth Sci., 36, 1327-1344.

Kane, I.A., Kneller, B.C., Dykstra, M., Kassem, A. and McCaffrey, W.D. (2007) Anatomy of a submarine channellevee: An example from the Rosario Formation, Baja California, Mexico. Mar. Pet. Geol., 24, 540-563.

Kane, I.A., McCaffrey, W.D., Peakall, J. and Kneller, B.C. (2010) Submarine channel levee shape and sediment waves from physical experiments. Sed. Geol., 223, 75-85.

Klinger, Y., Avouac, J.P., Bourles, D. and Tisnerat, N. (2003) Alluvial deposition and lake-level fluctuations forced by Late Quaternary climate change: the Dead Sea case example. Sed. Geol., 162, 119-139.

Korus, J.T. and Fielding, C.R. (2015) Asymmetry in Holocene river deltas: Pattern, controls, and stratigraphic effects. Earth Sci. Rev., 150, 219-242.

Kostic, S. and Parker, G. (2006) The response of turbidity currents to a canyon-fan transition: internal hydraulic jumps and depositional signatures. J. Hydraul. Res., 44, 631-653.

Lajeunesse, P. (2014) Buried preglacial fluvial gorges and valleys preserved through Quaternary glaciations beneath the eastern Laurentide Ice Sheet. Geol. Soc. Am. Bull., 126, 447-458.

Lajeunesse, P. (in press) Late-Wisconsinan grounding-zone wedges, northwestern Gulf of St. Lawrence (eastern Canada). In: Atlas of Submarine Glacial Landforms (Eds J. Dowdeswell, M. Canals, M. Jakobsson, B.J. Todd, E.K. Dowdeswell and K.A. Hogan), Available at: http:// www.submarineglacialatlas.com/contributions/accepted/.

Lajeunesse, P. and Allard, M. (2002) Sedimentology of an ice-contact glaciomarine fan complex, Nastapoka Hills, eastern Hudson Bay, northern Québec. Sed. Geol., 152, 201-220.

Le Heron, D.P., Craig, J., Sutcliffe, O.E. and Whittington, R. (2006) Late Ordovician glaciogenic reservoir heterogeneity: An example from the Murzuq Basin, Libya. Mar. Pet. Geol., 23, 655-677.
Le Heron, D.P., Cox, G., Trundley, A. and Collins, A.S. (2011) Two Cryogenian glacial successions compared: Aspects of the Sturt and Elatina sediment records of South Australia. Precambr. Res., 186, 147-168.

Le Heron, D.P., Busfield, M.E. and Kamona, F. (2013) An interglacial on snowball Earth? Dynamic ice behaviour revealed in the Chuos Formation, Namibia. Sedimentology, 60, 411-427.

Leeder, M.R. and Stewart, M.D. (1996) Fluvial incision and sequence stratigraphy: alluvial responses to relative sealevel fall and their detection in the geological record. In: Sequence Stratigraphy in British Geology (Eds S.P. Hesselbo and D.N. Parlinson), 103, pp. 25-39. Geological Society Special Publication, Xxxxxxx.

Leverington, D.W., Teller, J.T. and Mann, J.D. (2002) A GIS method for reconstruction of late Quaternary landscapes from isobase data and modern topography. Comput. Geosci., 28, 631-639.

Loi, A., Ghienne, J.-F., Dabard, M.P., Paris, F., Botquelen, A., Christ, N., Elaouad-Debbaj, Z., Gorini, A., Vidal, M., Videt, B. and Destombes, J. (2010) The Late Ordovician glacio-eustatic record from a high-latitude stormdominated shelf succession: The Bou Ingarf section (AntiAtlas, Southern Morocco). Palaeogeogr. Palaeoclimatol. Palaeoecol., 296, 332-358.

Long, B.F., Sala, M., Durand, J. and Michaud, L. (1989) Géométrie d'un lobe deltaïque en contexte régressif. Bull. Centres Rech. Explor.-Prod. Elf-Aquitaine, 13, 189-213.

Lønne, I. (1995) Sedimentary facies and depositional architecture of ice-contact glaciomarine systems. Sed. Geol., 98, 13-43.

Lønne, I. and Nemec, W. (2004) High-arctic fan delta recording deglaciation and environment disequilibrium. Sedimentology, 51, 553-589.

Maizels, J. (2002) Sediments and landforms of modern proglacial terrestrial environments. In: Modern \& Past Glacial Environments, pp. 279-316. (Ed. J. Menzies), Butterworth HeinemannLondon.

Margold, M., Stokes, C.R. and Clark, C.D. (2015) Ice streams in the Laurentide Ice Sheet: Identification, characteristics and comparison to modern ice sheets. Earth Sci. Rev., 143, 117-146.

Massari, F. and Parea, G.C. (1990) Wave-dominated Gilberttype gravel deltas in the hinterland of the Gulf of Taranto (Pleistocene, southern Italy). In: Coarse-Grained Deltas (Eds A. Colella and D.B. Prior). IAS Spec. Pub., pp. ????-????. Blackwell Scientific Publication, Xxxxxxx.

McMurray, L.S. and Gawthorpe, R.L. (2000) Along-strike variability of forced regressive deposits: late Quaternary, northern Peloponnesos, Greece. In: Sedimentary Responses to Forced Regressions (Eds D. Hunt and R.L. Gawthorpe), 172, pp. 363-378, Geological Society Special Publication.

Meistrell, F.J. (1972) The spit-platform concept: laboratory observation of spit development. In: Spits and Bars, pp. 225-283. (Ed. M.L. Schwartz), Dowden, Hutchinson and Ross, Stroudsberg, PA.

Mulder, T. and Syvitski, J.P. (1995) Turbidity Currents Generated at River Mouths during Exceptional Discharges to the World Oceans. J. Geol., 103, 285-299.

Nemec, W., Lønne, I. and Blikra, L.H. (1999) The Kregnes moraine in Gauldalen, west-central Norway: anatomy of a Younger Dryas proglacial delta in a palaeofjord basin. Boreas, 28, 454-476.

Nielsen, L.H. and Johannessen, P.N. (2009) Facies architecture and depositional processes of the Holocene- 
Recent accretionary forced regressive Skagen spit system, Denmark. Sedimentology, 56, 935-968.

Normandeau, A. (2011) Transfert sédimentaire extracôtier récent via un système chenal-levee au large de Sept-Îles, Est du Québec. In: Master. Université Laval, Xxxxxxx.

Normandeau, A., Lajeunesse, P., St-Onge, G., Bourgault, D., Drouin, S.S.-O., Senneville, S. and Bélanger, S. (2014) Morphodynamics in sediment-starved inner-shelf submarine canyons (Lower St. Lawrence Estuary, Eastern Canada). Mar. Geol., 357, 243-255.

Normandeau, A., Lajeunesse, P. and St-Onge, G. (2015) Submarine canyons and channels in the Lower St. Lawrence Estuary (Eastern Canada): Morphology, classification and recent sediment dynamics. Geomorphology, 241, 1-18.

Nutz, A., Ghienne, J.-F., Schuster, M., Certain, R., Robin, N., Roquin, C., Raynal, O., Bouchette, F., Duringer, P. and Cousineau, P.A. (2014) Seismic-Stratigraphic Record of a Deglaciation Sequence: from the Marine Laflamme Gulf to Lake Saint-Jean (Late Quaternary. Boreas, Québec, Canada).

Nutz, A., Schuster, M., Ghienne, J.-F., Roquin, C., Hay, M.B., Rétif, F., Certain, R., Robin, N., Raynal, O., Cousineau, P.A., Team, S. and Bouchette, F. (2015) Winddriven bottom currents and related sedimentary bodies in Lake Saint-Jean (Québec, Canada). Geol. Soc. Am. Bull., 127, 1194-1208.

Ó Cofaigh, C. and Dowdeswell, J.A. (2001) Laminated sediments in glacimarine environments: diagnostic criteria for their interpretation. Quatern. Sci. Rev., 20, 1411-1436.

Occhietti, S. (2007) The Saint-Narcisse morainic complex and early Younger Dryas events on the southeastern margin of the Laurentide Ice Sheet. Géog. Phys. Quatern., 61, 89-117.

Occhietti, S., Govare, É., Klassen, R., Parent, M. and Vincent, J.-S. (2004) Late Wisconsinian - Early Holocene deglaciation of Québec-Labrador. In: Quaternary Glaciations - Extent and Chronology, Part II, pp. 243-273. (Eds J. Ehlers and P.L. Gibbard), Elsevier, New York.

Occhietti, S., Parent, M., Lajeunesse, P., Robert, F. and Govare, É. (2011) Late Pleistocene-Early Holocene Decay of the Laurentide Ice Sheet in Québec-Labrador. Xxхxxx, 15, 601-630.

Pazos, P.J. (2002) The Late Carboniferous Glacial to Postglacial Transition: Facies and Sequence Stratigraphy, Western Paganzo Basin, Argentina. Gondwana Res., 5, 467-487.

Peltier, W.R. and Fairbanks, R.G. (2006) Global glacial ice volume and Last Glacial Maximum duration from an extended Barbados sea level record. Quatern. Sci. Rev., 25, 3322-3337.

Plink-Björklund, P. and Steel, R.J. (2004) Initiation of turbidity currents: outcrop evidence for Eocene hyperpycnal flow turbidites. Sed. Geol., 165, 29-52.

Plint, A.G. and Nummedal, D. (2000) The falling stage systems tract: recognition and importance in sequence stratigraphic analysis. Geol. Soc. Spec. Publ., 172, 1-17.

Pomar, L., Morsilli, M., Hallock, P. and Bádenas, B. (2012) Internal waves, an under-explored source of turbulence events in the sedimentary record. Earth Sci. Rev., 111, 56-81.

Porebski, S.J. and Steel, R.J. (2006) Deltas and Sea-Level Change. J. Sediment. Res., 76, 390-403.

Posamentier, H.W. and Morris, W.R. (2000) Aspects of the stratal architecture of forced regressive deposits. Geol. Soc. Spec. Publ., 172, 19-46.
Postma, G. and Cartigny, M.J.B. (2014) Supercritical and subcritical turbidity currents and their deposits - A synthesis. Geology, 42, 987-990.

Postma, G., Cartigny, M. and Kleverlaan, K. (2009) Structureless, coarse-tail graded Bouma Ta formed by internal hydraulic jump of the turbidity current? Sed. Geol., 219, 1-6.

Powell, R.D. and Cooper, J.M. (2002) A glacial sequence stratigraphic model for temperate, glaciated continental shelves. In: Xxхxхx (Eds J.A. Dowdeswell and C. Cofaigh), Geological Society, London, Special Publications 203, 215-244.

Prince, G.D. and Burgess, P.M. (2013) Numerical Modeling of Falling-Stage Topset Aggradation: Implications for Distinguishing Between Forced and Unforced Regressions In the Geological Record. J. Sediment. Res., 83, 767-781.

Proust, J.-N. and Deynoux, M. (1990) Marine to non-marine sequence architecture of an intracratonic glacially related basin. Late Proterozoic of the West African platform in western Mali. In: Earth's Glacial Record (Eds M. Deynoux, J.M.G. Miller, E.W. Domack, N. Eyles, I.J. Fairchild and G.M. Young), World and Regional Geology, pp. 121-145. Cambridge University Press, Xxxxxxxx.

Rabineau, M., Berné, S., Aslanian, D., Olivet, J.-L., Joseph, P., Guillocheau, F., Bourillet, J.-F., Ledrezen, E. and Granjeon, D. (2005) Sedimentary sequences in the Gulf of Lion: A record of 100,000 years climatic cycles. Mar. Pet. Geol., 22, 775-804.

Reading, H.G. and Collinson, J.D. (1996) Clastic coasts. In: Sedimentary Environments: Processes, Facies and Stratigraphy (Ed. H.G. Reading), pp. 154-231. Blackwell, Xxxxxxxx.

Reimer, P.J., Baillie, M.G.L., Xxxxx, E., Bayliss, A., Beck, J.W., Blackwell, P.G., Bronk Ramsey, C., Buck, C.E., Burr, G.S., Edwards, R.L., Friedrich, M., Grootes, P.M., Guilderson, T.P., Hajdas, I., Heaton, T.J., Hogg, A.G., Hughen, K.A., Kaiser, K.F., Kromer, B., McCormac, F.G., Manning, S.W., Reimer, R.W., Richards, D.A., Southon, J.R., Talamo, S., Turney, C.S.M., van der Plicht, J. and Weyhenmeyer, C.E. (2009) IntCal09 and Marine09 radiocarbon age calibration curves, 0-50,000 years Cal BP. Radiocarbon, 51, 1111-1150.

Runkel, A.C., Mackey, T.J., Cowan, C.A. and Fox, D.L. (2010) Tropical shoreline ice in the late Cambrian: Implications for Earth's climate between the Cambrian Explosion and the Great Ordovician Biodiversification Event. GSA Today, ????, 4-10.

Russell, A.J. and Arnott, R.W.C. (2003) Hydraulic-jump and hyperconcentrated-flow deposits of a glacigenic subaqueous fan: Oak Ridges Moraine, Southern Ontario, Canada. J. Sediment. Res., 3, 887-905.

Russell, H., Sharpe, D. and Bajc, A. (2009) Sedimentary signatures of the Waterloo Moraine, Ontario, Canada. Glacial Processes Prod. Int. Assoc. Sedimentol. Spec. Publ., 39, 85-108.

Sala, M. and Long, B. (1989) Evolution des structures deltaïques du delta de la rivière Natashquan, Québec. Géog. Phys. Quatern., 43, 311-323.

Santra, M., Goff, J.A., Steel, R.J. and Austin, J.A. (2013) Forced regressive and lowstand Hudson paleo-Delta system: Latest Pliocene growth of the outer New Jersey shelf. Mar. Geol., 339, 57-70.

Saucier, F.J. and Chassé, J. (2000) Tidal circulation and buoyancy effects in the St. Lawrence Estuary. AtmosphereOcean, 38, 505-556. 
Schumm, S.A. (1993) River response to baselevel change: implications for sequence stratigraphy. J. Geol., 101, 279294.

Shaw, J. and Forbes, D.L. (1992) Barriers, barriers platform and spillover deposits in St George's Bay, Newfoundland: Paraglacial sedimentation on the flanks of a deep coastal basin. Mar. Geol., 105, 119-140.

Shaw, J., Gareau, P. and Courtney, R.C. (2002) Palaeogeography of Atlantic Canada 13-0kyr. Quatern. Sci. Rev., 21, 1861-1878.

Shaw, J., Piper, D.J.W., Fader, G.B.J., King, E.L., Todd, B.J., Bell, T., Batterson, M.J. and Liverman, D.G.E. (2006) A conceptual model of the deglaciation of Atlantic Canada. Quatern. Sci. Rev., 25, 2059-2081.

Smith, N.D., Phillips, A.C. and Powell, R.D. (1990) Tidal drawdown: A mechanism for producing cyclic sediment laminations in glaciomarine deltas. Geology, 18, 10-13.

Sorrel, P., Debret, M., Billeaud, I., Jacard, S.L., McManus, J.F. and Tessier, B. (2012) Persistent non-solar forcing of Holocene storm dynamics in coastal sedimentary archives. Nat. Geosci. Lett., 5, ????-????.

St-Onge, G., Lajeunesse, P., Duchesne, M.J. and Gagné, H. (2008) Identification and dating of a key Late Pleistocene stratigraphic unit in the St. Lawrence Estuary and Gulf (Eastern Canada). Quatern. Sci. Rev., 27, 2390-2400.

Storms, J.E.A., de Winter, I.L., Overeem, I., Drijkoningen, G.G. and Lykke-Andersen, H. (2012) The Holocene sedimentary history of the Kangerlussuaq Fjord-valley fill, West Greenland. Quatern. Sci. Rev., 35, 29-50.

Swenson, J.B. and Muto, T. (2007) Response of coastal plain rivers to falling relative sea-level: allogenic controls on the aggradational phase. Sedimentology, 54, 207-221.

Swenson, J.B., Paola, C., Pratson, L., Voller, V.R. and Murray, A.B. (2005) Fluvial and marine controls on combined subaerial and subaqueous delta progradation: Morphodynamic modelling of compound-clinoform development. J. Geophys. Res., 110, 1-16.

Swift, D.J.P., Parsons, B.S., Foyle, A. and Oertel, G.F. (2003) Between beds and sequences: stratigraphic organization at intermediate scales in the Quaternary of the Virginia coast, USA. Sedimentology, 50, 81-111.

Syvitski, J.P.M. (1989) On the deposition of sediment within glacier-influenced fjords: oceanographic controls. Mar. Geol., 85, 301-329.

Syvitski, J.P. and Farrow, G.E. (1983) Structures and processes in bayhead deltas: Knight and Bute Inlet, British Columbia. Sed. Geol., 36, 217-244.

Syvitski, J.P.M. and Hein, F.J. (1991) Sedimentology of an Arctic Basin: Itirbilung Fiord. Baffin Island, Northwestern Territories, $66 \mathrm{pp}$.

Syvitski, J.P. and Lee, H.J. (1997) Postglacial sequence stratigraphy of Lake Melville, Labrador. Mar. Geol., 143, $55-79$.

Syvitski, J.P.M. and Praeg, D.B. (1989) Quaternary Sedimentation in the St. Lawrence Estuary and Adjoining Areas, Eastern Canada: An Overview Based on HighResolution Seismo-Stratigraphy. Géographie physique et. Quaternaire, 43, 291.

Tarasov, L., Dyke, A.S., Neal, R.M. and Peltier, W.R. (2012) A data-calibrated distribution of deglacial chronologies for the North American ice complex from glaciological modeling. Earth Planet. Sci. Lett., 315-316, 30-40.

Tesson, M., Posamentier, H.W. and Gensous, B. (2000) Stratigraphic Organization of Late Pleistocene deposits of the western part of the Golfe du Lion shelf
(Languedoc Shelf), Western Mediterranean Sea, Using high-resolution seismis and core data. AAPG Bull., 54, 119-150.

Thériault, R., Beauséjour, S. and Tremblay, A. (2012) Géologie du Québec. Gouvernement du Québec, Ministère des Ressources Naturelles, Direction de l'information géologique du Québec, Québec City.

Tooth, S., Brandt, D., Hancox, P.J. and McCarthy, T.S. (2004) Geological controls on alluvial river behaviour: a comparative study of three rivers on the South African Highveld. J. Afr. Earth Sc., 38, 79-97.

Tremblay, A., Long, B. and Massé, M. (2003) Supracrustal faults of the St. Lawrence rift system, Québec: kinematics and geometry as revealed by field mapping and marine seismic reflection data. Tectonophysics, $\mathbf{3 6 9}$, 231-252.

Tremblay, A., Roden-Tice, M.K., Brandt, J.A. and Megan, T.W. (2013) Mesozoic fault reactivation along the St. Lawrence rift system, eastern Canada: Thermochronologic evidence from apatite fission-track dating. Geol. Soc. Am. Bull., 125, 794-810.

Turmel, D., Locat, J. and Parker, G. (2015) Morphological evolution of a well-constrained, subaerial-subaqueous source to sink system: Wabush Lake. Sedimentology, 62, 1636-1664.

Visser, J.N.J. (1997) Deglaciation sequences in the PermoCarboniferous Karoo and Kalahari basins of southern Africa: a tool in the analysis of cyclic glaciomarine basin fills. Sedimentology, 44, 50-521.

Zavala, C., Arcuri, M. and Di Meglio, M. (2010) A Genetic Facies Tract for the Analysis of Sustained Hyperpycnal Flow Deposits. In: Sediment Transfer from Shelf to Deep Water-Revisiting the Delivery System (Eds R.M. Slatt and C. Zavala), AAPG Studies in Geology, 61, 1-21.

Zecchin, M. (2007) The architectural variability of smallscale cycles in shelf and ramp clastic systems: The controlling factors. Earth Sci. Rev., 84, 21-55.

Zecchin, M., Caffau, M., Civile, D. and Roda, C. (2010) Anatomy of a late Pleistocene clinoformal sedimentary body (Le Castella, Calabria, southern Italy): A case of prograding spit system? Sed. Geol., 223, 291-309.

Manuscript received 11 August 2015; revision accepted 21 October 2016

\section{Supporting Information}

Additional Supporting Information may be found in the online version of this article:

Figure S1. (A) Landform distribution over the Portneuf Peninsula. Bedrock outcrops in grey, ice-contact deposits in red (from Cousineau et al., 2014); red arrows: glacial striations and/or crescent marks on bedrock; green lines: networks of braided channels; orange: coastal landforms, mainly raised beach ridges. (B) Panoramic picture of one of the active meanders of the Sault-au-Cochon river.

Figure S2. Details of two selected segments of the cliff (location in Fig. 2). (A) the northernmost segment $(\mathrm{km} 7 \cdot 0$ to $7 \cdot 7)$, from esker (DU1) to delta plain (DU6) deposits. Note draping and onlapping geometries of glaciomarine mud (DU2) above the upwardly-convex 